\title{
Development of Two-Dimensional Nanomaterials Based Electrochemical Biosensors on Enhancing the Analysis of Food Toxicants
}

\author{
Iruthayapandi Selestin Raja ${ }^{1,+}{ }^{+}$, Mohan Vedhanayagam ${ }^{2,+}{ }^{\dagger}$ Desingh Raj Preeth ${ }^{3}$, Chuntae Kim ${ }^{1}$, \\ Jong Hun Lee ${ }^{4, * \mathbb{D}}$ and Dong Wook Han $1,5, * \mathbb{D}$
}

check for

updates

Citation: Raja, I.S.; Vedhanayagam, M.; Preeth, D.R.; Kim, C.; Lee, J.H.; Han, D.W. Development of

Two-Dimensional Nanomaterials Based Electrochemical Biosensors on Enhancing the Analysis of Food Toxicants. Int. J. Mol. Sci. 2021, 22, 3277. https://doi.org/10.3390/ ijms22063277

Academic Editor: Maciej Jarzębski

Received: 23 February 2021

Accepted: 21 March 2021

Published: 23 March 2021

Publisher's Note: MDPI stays neutral with regard to jurisdictional claims in published maps and institutional affiliations.

Copyright: (c) 2021 by the authors. Licensee MDPI, Basel, Switzerland. This article is an open access article distributed under the terms and conditions of the Creative Commons Attribution (CC BY) license (https:// creativecommons.org/licenses/by/ $4.0 /)$.
1 BIO-IT Foundry Technology Institute, Pusan National University, Busan 46241, Korea; rajaselestin@gmail.com (I.S.R.); chuntae1122@gmail.com (C.K.)

2 CSIR-Central Leather Research Institute, Adyar, Chennai 600 020, India; msvedhanayagam@gmail.com

3 Chemical Biology and Nanobiotechnology Laboratory, AU-KBC Research Centre, Anna University, MIT Campus, Chromepet, Chennai 600 044, India; preeth1905@gmail.com

4 Department of Food Science and Biotechnology, Gachon University, Seongnam 13120, Korea

5 Department of Cogno-Mechatronics Engineering, College of Nanoscience \& Nanotechnology, Pusan National University, Busan 46241, Korea

* Correspondence: foodguy@gachon.ac.kr (J.H.L.); nanohan@pusan.ac.kr (D.W.H.)

+ These authors contributed equally to this work.

\begin{abstract}
In recent times, food safety has become a topic of debate as the foodborne diseases triggered by chemical and biological contaminants affect human health and the food industry's profits. Though conventional analytical instrumentation-based food sensors are available, the consumers did not appreciate them because of the drawbacks of complexity, greater number of analysis steps, expensive enzymes, and lack of portability. Hence, designing easy-to-use tests for the rapid analysis of food contaminants has become essential in the food industry. Under this context, electrochemical biosensors have received attention among researchers as they bear the advantages of operational simplicity, portability, stability, easy miniaturization, and low cost. Two-dimensional (2D) nanomaterials have a larger surface area to volume compared to other dimensional nanomaterials. Hence, researchers nowadays are inclined to develop 2D nanomaterials-based electrochemical biosensors to significantly improve the sensor's sensitivity, selectivity, and reproducibility while measuring the food toxicants. In the present review, we compile the contribution of 2D nanomaterials in electrochemical biosensors to test the food toxicants and discuss the future directions in the field. Further, we describe the types of food toxicity, methodologies quantifying food analytes, how the electrochemical food sensor works, and the general biomedical properties of 2D nanomaterials.
\end{abstract}

Keywords: food safety; food toxicants; electrochemical biosensor; 2D nanomaterials

\section{Introduction}

The variety and quantity of food have increased dramatically as the food industry and modern agriculture are developed. Meanwhile, food safety holds a significant socioeconomic impact creating awareness among consumers [1,2]. Food safety is generally threatened by some molecular species, including pesticides, veterinary drug residues, heavy metals, pathogens, and toxins [3-5]. The presence of excessive chemical and biological toxins in food represents a serious threat to food safety and public health and reduces the food industry's profits [6-8]. There was an increasing demand for strict testing for food toxicants, which has led to intensive research in food sensors. The World Health Organization (WHO) estimates that foodborne illnesses predominantly affect underdeveloped nations' economies and placed food safety among its top 11 priorities $[9,10]$.

Earlier liquid chromatography-based methods, including high-performance liquid chromatography (HPLC) and high-performance liquid chromatography coupled with 
tandem mass spectrometry (HPLC/MS/MS), were used for the accurate quantification of toxins $[11,12]$. Although these methods have more reliability and accuracy, they require expensive laboratory facilities, complex pre-treatment processing of the sample, and skilled operators [13,14]. Due to these drawbacks, HPLC-based methods' application is limited in the on-site analysis of toxins [15]. Researchers have developed various sensing techniques over the past two decades, such as colorimetric assays, fluorescence biosensors, competitive enzyme-linked immunosorbent assays, microfluidic immunoassays, surface plasmon resonance biosensors, and electrochemical biosensors for the analysis of toxins in food, water, and clinical samples [16-19]. Among these biosensing systems, electrochemical biosensors/transducers of food toxins have become powerful tools offering several advantages such as operational simplicity, high sensitivity, easy miniaturization, relatively low cost, and suitable on-site analysis [20-22]. This technique expedites the screening process of food contamination and enables the remedial measurements to be taken promptly to manage the problems related to foodborne ailments.

Nanotechnology-derived products have offered a wide range of material candidates to increase the stability, selectivity, and sensitivity of electrochemical sensors $[23,24]$. The nanomaterials applied in the food industry have beneficial properties, such as drug encapsulation and delivery, antioxidant and antimicrobial property, and food additives increasing the food products' flavor and shelf-life $[1,10,25]$. The functional nanomaterials produce a combined effect on catalytic activity, signal transduction, and high specificity on recognizing different molecules in electrochemistry-based devices. Hence, the construction of active nanomaterial-modified electrodes is extensively applied for food safety measurement [26-28]. As the two-dimensional (2D) nanomaterials exhibit a larger surface area to volume, they have been preferential candidates in designing various biosensors [29-31]. In the present review, we focus on developing 2D nanomaterials-based biosensors to detect food contaminants in real sample analysis. Apart from that, we highlight different types of food toxicity, various electrochemical methodologies to determine food toxicants, and the mechanism of electrochemical sensors.

\subsection{Description of Food Toxicants}

Food additives, chemical contaminants, and microbial contaminants are the three kinds of food analytes [32]. Food additives are included in food and drink items to produce desired color and flavor; however, overconsumption of additives can cause adverse effects to the human body [33,34]. The scientific reports reveal that a high caffeine dose can cause irritability, oversensitivity, and insomnia [35]. The primary public concern about food safety is to ensure strict control of the food additive concentration in food items geared toward growing children. Unlike the additives, the contaminants are not included in the food items intentionally [36]. Chemical contaminants, such as pesticides and veterinary drugs, significantly reduce food quality in food processing and storage. In general, the family of $\beta$-agonists, including ractopamine, cimaterol, clenbuterol, and salbutamol, is used to improve the carcass leanness in livestock species [37,38]. The scientific reports reveal that such $\beta$-agonists cause several potential hazardous effects such as cardiac palpitation, nervousness, tachycardia, muscle tremors, and confusion [39,40]. Bacterial pathogens such as Salmonella (31\%), Listeria (28\%), Campylobacter (5\%), and Escherichia coli O157:H7 $(3 \%)$ species are the causative agents of microbial contamination [41]. They trigger water and food-borne diseases threatening human health [42]. Electrochemical biosensors are sensitive to detect even trace amounts of food analytes due to their high specificity of biological reaction combined with electrochemical techniques. Electrochemical biosensors important characteristics are amenability to miniaturization, dynamic concentration range, instant response to the analytes, and stability at varying environmental factors such as temperature and $\mathrm{pH}[21,22]$. Figure 1 demonstrates the measurement of different types of food toxic analytes using an electrochemical biosensor to ensure food safety. 


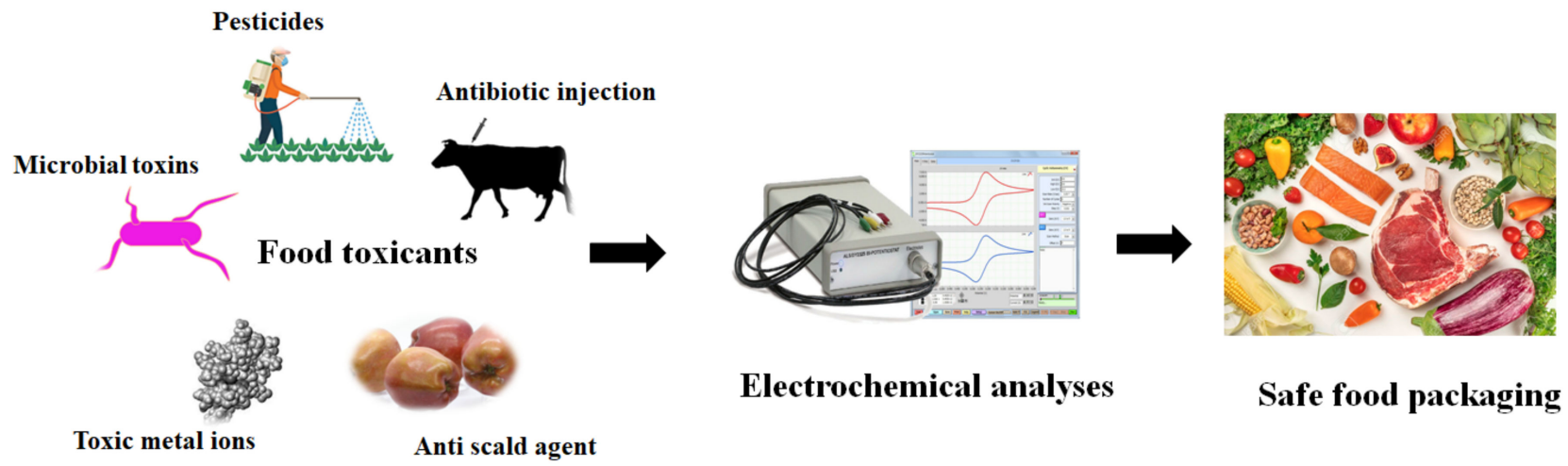

Figure 1. Ensuring food safety through electrochemical analyses of food toxic analytes from different sources has been shown schematically.

\subsection{Classification of Electrochemical Biosensors}

We have exemplified the basic principle and the types of electrochemical biosensors in this section. The electrochemical biosensors work on the principle that an electrochemical signal is generated when the desired analyte is either oxidized or reduced upon the fixed or varying potential. The variation in electron fluxes is measured by the detector Figure 2A [43]. The biosensing surface may include any biological elements such as enzymes, antibodies, antigens, microorganisms, receptors, mammalian cells, and tissues immobilized on the transducer surface $[44,45]$. The biological elements bind the analyte (food toxicants) molecules selectively, and the surface of a transducer converts the event into a measurable electrical signal, voltage, or current [46]. Eventually, the electrochemical technique and the signal processor receive, magnify, and display the signal.

Depending on the biomolecular element's detection mechanism, electrochemical biosensors can be categorized into biocatalytic and affinity sensors [47]. Biocatalytic sensors monitor the enzyme-target reaction to produce electroactive molecules. In contrast, affinity sensors, including aptasensors, immunosensors, and DNA sensors, observe the interaction between the bioreceptor and the target to generate a measurable signal [48]. A combination of signal transduction and biological receptor can also be described as an electrochemical affinity sensor. For instance, impedimetric immunosensors utilize impedance spectroscopy and antibodies [49]. The electrochemical sensors can be described as labeled or label-free sensors depending on the use of labels for improving their detection mechanism [50].

A variety of electrochemical techniques employed for the detection of toxic analytes can be classified into the following general categories, potentiostatic, galvanostatic, potentiometric, and impedimetric sensors (Figure 2B) [51]. In the potentiostatic method, the applied controlled potential to the electrochemical cell is converted into the current. In contrast, the current is applied to measure the potential in the galvanostatic method. When the cell potential is assessed under the near-zero current condition, it is known as potentiometric. The impedance method applies the cell's potential, and the current response is measured to obtain impedance (complex resistance). The most common potentiostatic techniques in affinity electrochemical biosensors are amperometry and voltammetry, which apply a constant, scanning, or pulsing potential to a working electrode to measure the current [52].

Amperometry works on a fixed potential, whereas voltammetry examines a set of potential ranges to measure the current [53]. Voltammetric techniques, including cyclic voltammetry [54], normal and differential pulse voltammetry [37], and square wave voltammetry [55], have been extensively used for the analysis of various biological toxic analytes. Cyclic voltammetry is the commonly used electrochemical technique for the study of electroactive species. A characteristic cyclic voltammetric curve consists of a scanning trace from an initial potential to a switching potential followed by a reverse direction to the final potential [56]. Normal pulse voltammetry comprises a series of potential pulses with an increase in amplitude. The current response is evaluated near the end of each pulse when 
the interfering charging current decays away [51]. Differential pulse voltammetry scans the applied potential pulse of a constant amplitude through a fixed potential range and displays the difference in the two currents for the voltammogram [57]. In the square wave voltammetry technique, a symmetrical square wave is overlaid on a staircase waveform, and the difference in current between a forward and reverse pulse is computed. This technique has enhanced sensitivity for the analytes with faster scan rates than normal and differential pulse voltammetry methods [58].

Amperometric devices continuously measure the current resulting from redox reactions occurred by the electroactive species at a given potential. Clark oxygen electrodes, the simplest form of amperometric biosensors, produce current by reducing oxygen at a platinum working electrode in reference to a $\mathrm{Ag} / \mathrm{AgCl}$ reference electrode [59]. Amperometric sensors can measure the analytes directly or indirectly. Direct amperometry provides an intimate relationship between the measured current and the products of the redox reaction. In contrast, indirect amperometry utilizes conventional detectors to measure the desired analytes' metabolic substrate or product $[59,60]$. Amperometric techniques are mostly used to monitor various enzymatic reactions in a biocatalytic type biosensor.

When compared to the potentiostatic techniques, the usage of galvanostatic techniques in the biosensor is less. The chronopotentiometry method involves controlling the current between the working electrode and counter electrode and measuring the potential across them. It explores ion depletion at the membrane and sample interface and observes an inflection of the potential-time trace [61]. The potentiometric sensor investigates the potential difference between the working electrode and the reference electrode and displays the accumulation of charges at zero current created by the electrode surface [16]. The generation of potentiometric signals relies on a permselective transfer of analyte ions from the aqueous phase to the organic phase, which, in turn, creates a charge separation between the two phases [62]. Ion-selective electrodes and ion-selective field-effect transistors are the main components of potentiometric biosensors.

In the past two decades, electrochemical impedance spectroscopy (EIS) has been a robust technique as it can measure the analytes without using labels to produce a detectable signal [63]. One can measure the complex impedance, the sum of the real and imaginary components, by applying an alternating potential signal to the electrochemical cell varying a wide range of frequencies [64]. The impedance components, such as resistance and capacitance, provide information about the surface reactions and interface properties [65]. As the EIS measurement does not require sample preparation, it can be used for inline checking of food toxicants in the food supply chain. Scientific reports reveal that EIS can analyze food hazards in less than $1 \mathrm{~h}$ [66]. Further, the use of EIS in the food industry has been abundant, including for fruits, such as ripening of banana and dry matter of durian, for vegetables such as moisture content of carrots during drying, and changes in spinach tissue during heating. It helps evaluate discrimination of fresh and frozen-thawed chicken breast muscles, determination of the additives in natural juices, and bovine milk adulteration [67]. 
(A)

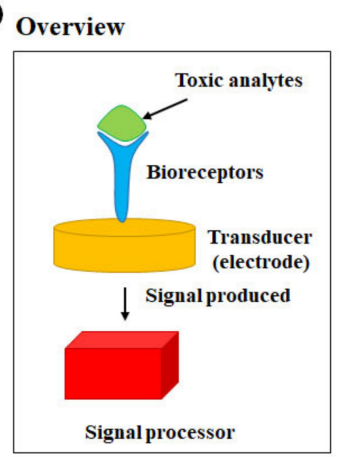

Bioreceptors

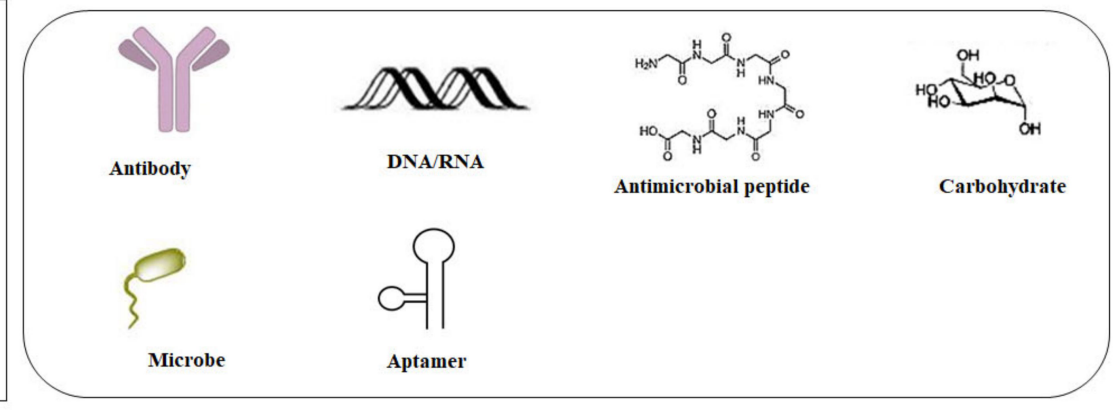

Transducer
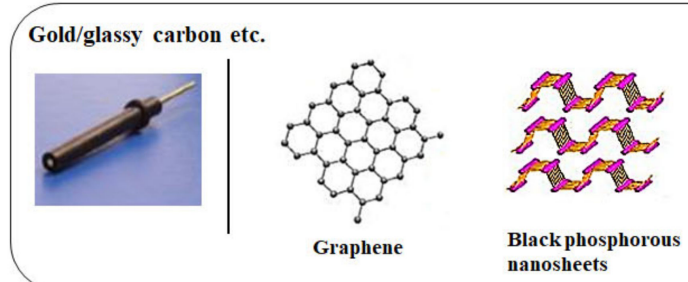

Nanomaterials (2D)
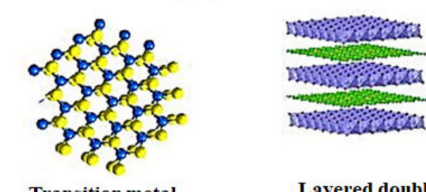
Transition metal
dichalcogenides

Layered double hydroxides

(B)

Electrochemical transduction/techniques

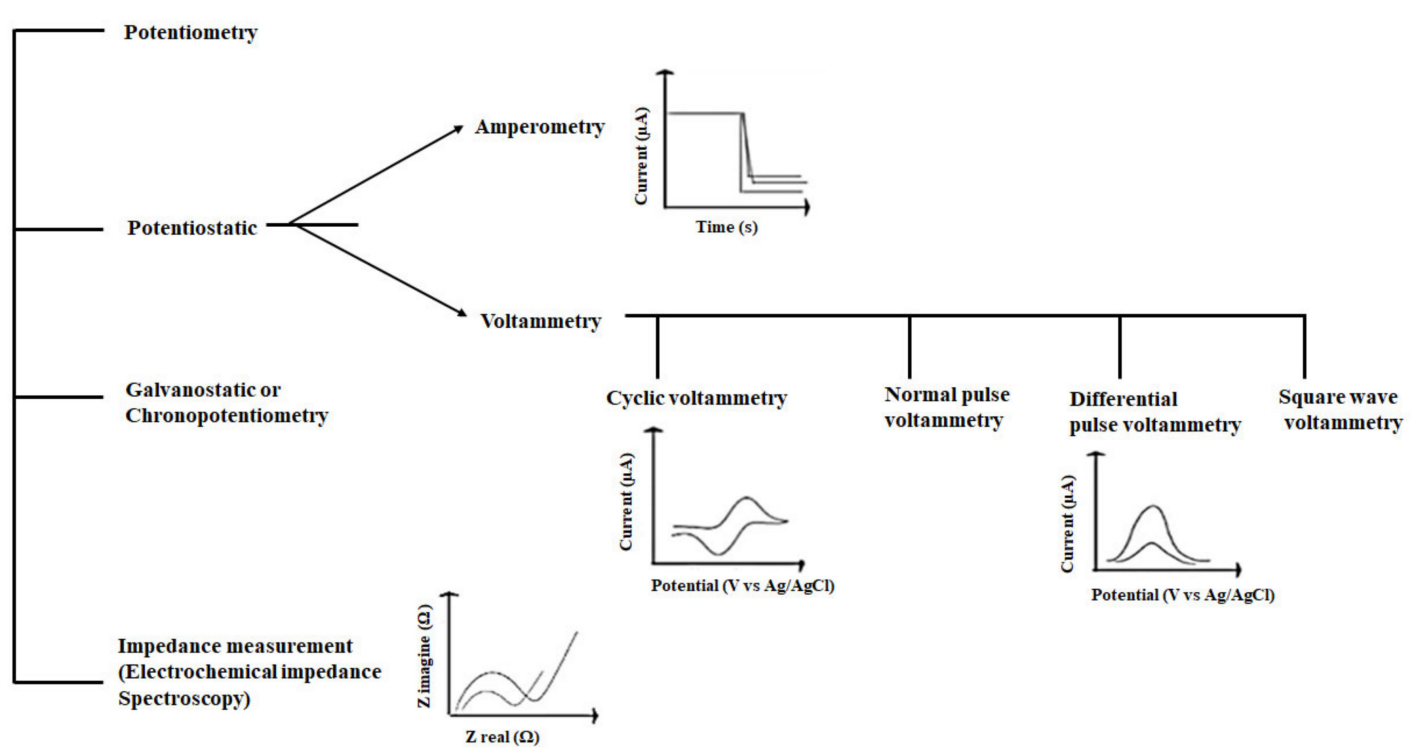

Figure 2. (A) Schematic illustration of a typical electrochemical food sensor and its various components, including bioreceptors, transducer, and signal processor [68]. The structure of two-dimensional nanomaterials used to fabricate the electrode surfaces in biosensors has been shown [69]. (B) Different types of electrochemical techniques have been presented [51].

\subsection{D Nanomaterials Improving Electrochemical Biosensors' Performance}

Nanomaterials used in electrochemical biosensors are mainly carbon-based nanomaterials [70-72], metal and metal oxide nanoparticles [73,74], and molecularly imprinted polymers $[75,76]$. The nature of the biosensing surface should exhibit prolonged stability for use and extended storage [77]. The nanomaterials incorporated in electrochemical biosensors improve response speed, sensitivity, and selectivity to meet the need for contaminant detection in food samples due to the nanomaterials' unique physicochemical and electrical properties [78,79].

2D nanomaterials exhibit a large surface-to-volume ratio compared to other dimensional (0D, 1D and 3D) nanomaterials [80-82]. They provide numerous anchoring sites for analytes' interaction, owing to their ultrathin planar nanostructure and large surface area, 
making them more suitable for sensor applications [83]. The 2D nanomaterials can display significantly higher conductivity than their $1 \mathrm{D}$ and 3D counterparts with their tunable electronic configuration and the resulting bandgap variation [84]. They express enhanced electrical properties leading to efficient signal transduction due to easily adjustable surface morphology [85]. The nanomaterials' atomic-size thickness plays an important role in showing variations in fluorescence, magnetic permeability, and chemical reactivity [86,87]. 2D nanomaterials have better compatibility with metal electrodes with large lateral sizes. The literature reports reveal that 2D nanomaterials show excellent compatibility with ultrathin silicon channel technology, whereas $0 \mathrm{D}, 1 \mathrm{D}$ and 3D nanomaterials face difficulties with device integration, establishing electrical contacts, and device miniaturization, respectively $[88,89]$. Some of the 2D nanomaterials exhibit better mechanical strength and remarkable optical properties [90-92]. The desired physicochemical properties in 2D nanomaterials could be achieved by introducing defect engineering, doping, and fine-tuning of structural properties during preparation $[93,94]$. Overall, the rich surface chemistry, conductive property, fluorescence, and compatibility of 2D nanomaterials make them very suitable candidates for health and environmental monitoring $[95,96]$.

2D nanomaterials include graphene family nanomaterials [97,98], MXene [99,100], transition metal dichalcogenides [101,102], single- elemental layered crystalline materials $[103,104]$, and metal oxides $[105,106]$. Among them, graphene family nanomaterials have been explored widely by researchers for food sensing applications [107-109]. Graphene family nanomaterials, including graphene oxide (GO), and reduced GO (rGO), and single and multilayered graphene, have a hexagonal lattice structure involving a single layer of $\mathrm{sp}^{2}$-hybridized carbon atoms covalently bound together $[110,111]$. The number of layers in graphene, intercalated by weak van der Waals forces, influences their physicochemical properties in several applications $[112,113]$. The graphite containing more than 10 layers is subjected to different physicochemical methods such as mechanical cleavage and electrochemical exfoliation to produce graphene sheets with single or few layers [114]. Chemical vapor deposition is a broadly utilized bottom-up approach to synthesize precisely controlled nanographene $[115,116]$. Graphene has been widely used in several biomedical applications, including drug carriers [117], tissue regeneration [118], and cancer treatment $[119,120]$ apart from biosensors [121,122]. Like graphene family nanomaterials, transition metal dichalcogenides, including molybdenum disulfide and molybdenum selenide, have shown remarkable physicochemical properties with biocompatibility, and have found significant advances in fabricating electrochemical biosensors [123-125]. Black phosphorus (BP) is composed of puckered lattice configuration and has exhibited more biocompatibility than other two-dimensional nanomaterials. Owing to unique semiconducting properties, anisotropic conductance, and larger hole mobility, they have been extensively applied in batteries and field-effect transistors. However, their application in electrochemistry is limited because of easy oxidization under normal conditions [126]. Cai et al. synthesized porous graphene-black phosphorous composite using a strong coherent coupling reaction. They used it to fabricate an electrochemical sensor to quantify bisphenol A, a food packaging material [127].

Among the metal oxides, manganese oxide $\left(\mathrm{MnO}_{2}\right)$ has been widely used as electrode material for its numerous redox electrochemical reactions and low cost. Though the theoretical capacitance of $\mathrm{MnO}_{2}$ is high $\left(1370 \mathrm{~F} \mathrm{~g}^{-1}\right)$, its maximum electrochemical capacitance is around $250 \mathrm{~F} \mathrm{~g}^{-1}$ only. The attributed reasons are poor electrical conductivity and less charge storage practice $[128,129]$. To avail a better capacitance performance, Thangarasu et al. fabricated an electrochemical sensor based on a nanocomposite of $\mathrm{MnO}_{2} / \mathrm{PANI} / \mathrm{rGO}$ to determine the level of methyl parathion, a pesticide [130].

Since 1987, the synthetic layered double hydroxides (LDH), known as anionic clays, have been used to modify electrodes. LDH materials have a lamellar structure with a high charge density of layers possessing intercalation properties. The net positive charge of the layer in LDH is maintained by the exchangeable anions intercalated between the octahedra forming sheets. The positively charged layers are the anchoring sites to immobilize the 
biomolecules, depending on their isoelectric point [131]. Shan et al. developed a LDH based electrochemical biosensor to immobilize polyphenol oxidase to determine toxic phenols [132].

MXenes, including 2D transition metal nitrides, carbides, or carbonitrides, are synthesized by etching out layer A selectively from parent MAX phases [133]. MAX phase contains alternating layers of $\mathrm{M}$ (transition metal) and $\mathrm{A}$ (group $\mathrm{A}$ element) with $\mathrm{X}$ (C or $\mathrm{N}$ ) to form a closely-packed multilayer structure. $\mathrm{Ti}_{3} \mathrm{C}_{2}$ is the most studied material among the synthesized 20 different MXenes. Owing to layered morphology, large surface area, hydrophilicity, thermal stability, and high electrical conductivity, MXenes have found numerous applications in electrochemical biosensors [134]. Briefly, integrating 2D nanomaterials and their nanocomposites with electrochemical transducers in biosensor has a great potential to improve their analytical performance. And the scope of 2D nanomaterial-based electrochemical biosensors has constantly been expanding in the field of food safety.

The architecture of the electrode surface can be controlled by fabricating with a highdensity array of nanomaterials. While doing so, the nanomaterials' intrinsic properties could be exploited at the electrode interface, enhancing the bioanalytical performance of a biosensor. For instance, Lu et al. have fabricated a GO-based electrochemical immunosensor to rapidly detect mycotoxins fumonisin B1 and deoxynivalenol [135]. The fabrication steps involve electrochemical deposition of polypyrrole (PPy)/GO nanocomposite film over a bare screen-printed carbon electrode. Subsequently, the GO was completely reduced to obtain PPy-electrochemically reduced graphene oxide (ErGO) nanocomposite film by cyclic voltammetry method. The resulting surface was drop-coated with AuNPs solution. Then, the modified electrode was immersed in 3-mercaptopropionic acid and EDC/NHS solutions to form an Au-S bond and activate the carboxyl groups, respectively. Finally, the electrode surface was immobilized with antibodies $(\mathrm{Ab})$ by incubating with anti-toxins at $\mathrm{pH} 9.0$ for $12 \mathrm{~h}$, as shown in Figure 3A. The electrochemical immunosensing of the developed biosensor to target mycotoxin has been illustrated in Figure 3B. DPV peak currents are measured for a blank sample and the samples containing mycotoxins. The Ab-toxin interaction at the electrode surface results in a decrease in DPV current, which is proportional to the $\mathrm{Ab}$ vs. toxin concentration in the samples. Hence, the difference between the DPV peaks of blank and samples helps quantify the number of target toxins present in the sample.

(A)
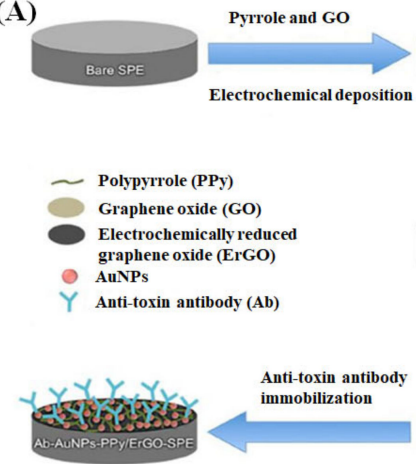
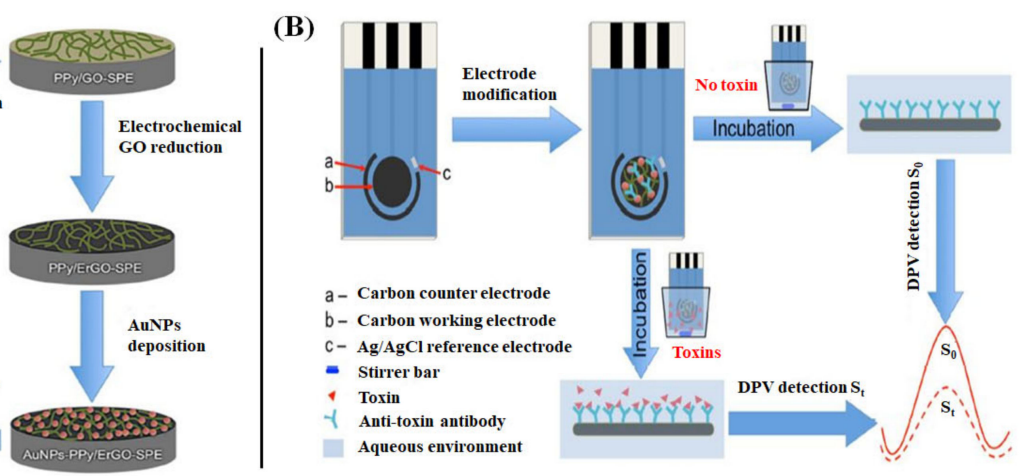

Figure 3. (A) Demonstration of step-by-step fabrication of the GO-based biosensor (antibody-Au NPspolypyrrole/electrochemically reduced GO-screen printed carbon electrode) and (B) electrochemical immunosensing of the system employed for the detection of mycotoxins through DPV signals [135].

\section{Food Toxicant Analyses of 2D Nanomaterial-Based Electrochemical Biosensors}

The role of 2D nanomaterials in electrochemical biosensors in sensing food toxicants has been summarized in Table 1. Various methodologies to detect food toxicity, linear range, and detection limit, and the value of recovery and repeatability in real sample analysis have also been described. 
Table 1. Contribution of 2D nanomaterials in electrochemical biosensors in sensing food toxicants.

\begin{tabular}{|c|c|c|c|c|c|c|c|c|}
\hline $\begin{array}{l}\text { 2D Nanomaterials } \\
\text { and Composites }\end{array}$ & Transducer/Complex & Methodology & Food Contaminants & $\begin{array}{l}\text { Linear Range; Limit } \\
\text { of Detection }\end{array}$ & $\begin{array}{l}\text { Real Sample } \\
\text { Application }\end{array}$ & $\begin{array}{c}\text { Recovery (\%); } \\
\text { Repeatability (\%) }\end{array}$ & Remarks & Study Authors \\
\hline Graphene & $\begin{array}{l}\text { BSA/antibody/4- } \\
\text { carboxyphenyl } \\
\text { diazonium } \\
\text { salt/GSPE }\end{array}$ & SWV & $\begin{array}{c}\text { Okadaic } \\
\text { acid/lipophilic marine } \\
\text { biotoxin }\end{array}$ & $\begin{array}{l}\sim 5000 \mathrm{ng} \mathrm{L}^{-1} \\
19 \mathrm{ng} \mathrm{L}^{-1}\end{array}$ & Shellfish extracts & $89.2-104 \% ; 5.8-10.9 \%$ & $\begin{array}{l}\text { Single-step and rapid; } \\
\text { reduced time and cost; } \\
\text { enhanced sensitivity } \\
\text { and specificity }\end{array}$ & $\begin{array}{l}\text { Eissa et al. } \\
\text { (2012) [136] }\end{array}$ \\
\hline Multilayer graphene & $\begin{array}{l}\text { LIG/multilayer } \\
\text { graphene }\end{array}$ & EIS & $\begin{array}{c}\text { Salmonella enterica } \\
\text { serovar } \\
\text { Typhimurium/food- } \\
\text { borne } \\
\text { pathogen }\end{array}$ & $\begin{array}{c}25 \text { to } 10^{5} \mathrm{CFU} \mathrm{mL}^{-1} \\
13 \pm 7 \mathrm{CFU} \mathrm{mL}^{-1}\end{array}$ & Chicken broth & nd:nd & $\begin{array}{l}\text { Low cost and } \\
\text { disposable; shelf life } \\
\text { for } 7 \text { days; inexpensive }\end{array}$ & $\begin{array}{l}\text { Soares et al. } \\
\text { (2020) [137] }\end{array}$ \\
\hline $\begin{array}{c}\text { Guanine-assembled } \\
\text { graphene } \\
\text { Nanoribbons } \\
\text { (GGNRs) }\end{array}$ & $\begin{array}{l}\text { Brevetoxin B } \\
\text {-BSA-GGNRs }\end{array}$ & SWV & $\begin{array}{l}\text { Brevetoxin } \\
\text { B/neurotoxin }\end{array}$ & $\begin{array}{l}1.0 \mathrm{pg} \mathrm{mL}^{-1} \text { to } \\
10 \mathrm{ng} \mathrm{mL}^{-1} ; \\
1.0 \mathrm{pg} \mathrm{mL}^{-1}\end{array}$ & $\begin{array}{l}\text { (Mollusk extracts) } \\
\text { Sinonovacula } \\
\text { constricta } \\
\text { Musculista senhousia } \\
\text { Tegillarca granosa }\end{array}$ & $\begin{array}{l}\text { 94-112\%; nd } \\
\text { 94-104\%; nd } \\
\text { 86-108\%; nd }\end{array}$ & $\begin{array}{l}\text { Enhanced sensitivity } \\
\text { equivalent to the } \\
\text { commercialized ELISA } \\
\text { method }\end{array}$ & $\begin{array}{l}\text { Tang et al. } \\
\text { (2012) [138] }\end{array}$ \\
\hline GO & $\begin{array}{c}\text { Bare/GO/EDC/ } \\
\text { aptamer/nanoceria } \\
\text { labeled ochratoxin A }\end{array}$ & $\mathrm{CV}$ & $\begin{array}{l}\text { Ochratoxin } \\
\text { A/mycotoxin }\end{array}$ & $0.15-180 \mathrm{nM} ; 0.1 \mathrm{nM}$ & Corn & $92.5-96 \% ; 3.1-4.3 \%$ & $\begin{array}{l}\text { Enhanced sensitivity } \\
\text { and selectivity }\end{array}$ & $\begin{array}{l}\text { Bulbul et al. } \\
\text { (2015) [139] }\end{array}$ \\
\hline GO & Polyaniline-GO & $\begin{array}{c}\text { FAAS and } \\
\text { electrochemical } \\
\text { assisted solid } \\
\text { phase extraction }\end{array}$ & $\begin{array}{l}\text { Lead }\left(\mathrm{Pb}^{2+}\right) / \text { toxic } \\
\text { metal ions }\end{array}$ & $\mathrm{ND} ; 0.04 \mu \mathrm{g} \mathrm{L}^{-1}$ & $\begin{array}{c}\text { Tap water, mineral } \\
\text { water, and beverage }\end{array}$ & nd: $0.14 \%$ & $\begin{array}{c}\text { Simple and rapid; } \\
\text { inexpensive and } \\
\text { eco-friendly; exhibiting } \\
\text { good anti-interference } \\
\text { property }\end{array}$ & $\begin{array}{l}\text { Wang et al. } \\
\text { (2018) [140] }\end{array}$ \\
\hline rGO & $\begin{array}{l}\text { Aptamer-AuNPs- } \\
\text { rGO-PGE }\end{array}$ & EIS & Tetracycline/antibiotic & $\begin{array}{l}1 \times 10^{-16} \\
1 \times 10^{-6} \mathrm{M} \\
3 \times 10^{-17} \mathrm{M}\end{array}$ & $\begin{array}{c}\text { Cow milk } \\
\text { Sheep milk } \\
\text { Goat milk } \\
\text { Water buffalo milk }\end{array}$ & $\begin{array}{c}94.2-96.1 \% ; 6.3-6.5 \% \\
92.8-98.4 \% ; 4.3-7.6 \% \\
95.7-97.1 \% ; 4.4-8.4 \% \\
97.7-102.1 \% ; \\
9.2-10.2 \%\end{array}$ & $\begin{array}{l}\text { Early screening; high } \\
\text { reproducibility; } \\
\text { stability for } 21 \text { days }\end{array}$ & $\begin{array}{l}\text { Mohammad- } \\
\text { Razdari et al. } \\
\text { (2020) [141] }\end{array}$ \\
\hline rGO & $\begin{array}{c}\mathrm{rGO} / \alpha- \\
\text { cyclodextrin/GCE }\end{array}$ & LSV & $\begin{array}{l}\text { Imidacloprid/ } \\
\text { neonicotinoid }\end{array}$ & $0.5-40 \mu \mathrm{M} ; 0.02 \mu \mathrm{M}$ & Brown rice & $92.0-98.7 \% ; 1.4-3.8 \%$ & $\begin{array}{l}\text { Excellent sensitivity, } \\
\text { selectivity, stability, } \\
\text { and reproducibility; } \\
\text { cost-effective and less } \\
\text { time-consumption }\end{array}$ & $\begin{array}{l}\text { Zhao et al. } \\
\text { (2020) [142] }\end{array}$ \\
\hline rGO & $\begin{array}{l}\text { rGO/Au/pyrenebutyric } \\
\text { acid/SNAP-25-GFP }\end{array}$ & DPV & $\begin{array}{l}\text { Botulinum neurotoxin } \\
\text { serotype A/neurotoxin }\end{array}$ & $\begin{array}{c}1 \mathrm{pg} / \mathrm{mL} \text { to } 1 \\
\mathrm{ng} / \mathrm{mL} ; 8.6 \mathrm{pg} / \mathrm{mL}\end{array}$ & Skimmed milk & nd: nd & $\begin{array}{l}\text { Increased sensitivity; } \\
\text { non-specificity }\end{array}$ & $\begin{array}{l}\text { Chan et al. } \\
\text { (2015) [143] }\end{array}$ \\
\hline $\mathrm{Fe}_{3} \mathrm{O}_{4} / \mathrm{rGO}$ & $\mathrm{Fe}_{3} \mathrm{O}_{4} / \mathrm{rGO} / \mathrm{MSPE}$ & DPV & $\begin{array}{c}\text { Ractopamine } / \beta- \\
\text { adrenergic } \\
\text { agonist }\end{array}$ & $\begin{array}{c}0.05-10 \text { and } \\
10-100 \mu \mathrm{M} ; 13 \mathrm{nM}\end{array}$ & Spiked real pork & $\begin{array}{l}90.13-109.63 \% \\
1.81-5.03 \%\end{array}$ & $\begin{array}{l}\text { Enhanced sensitivity; } \\
\text { portable; good } \\
\text { reproducibility }\end{array}$ & $\begin{array}{l}\text { Poo-arporn et al. } \\
\text { (2019) [144] }\end{array}$ \\
\hline
\end{tabular}


Table 1. Cont.

\begin{tabular}{|c|c|c|c|c|c|c|c|c|}
\hline $\begin{array}{l}\text { 2D Nanomaterials } \\
\text { and Composites }\end{array}$ & Transducer/Complex & Methodology & Food Contaminants & $\begin{array}{c}\text { Linear Range; Limit } \\
\text { of Detection }\end{array}$ & $\begin{array}{l}\text { Real Sample } \\
\text { Application }\end{array}$ & $\begin{array}{c}\text { Recovery (\%); } \\
\text { Repeatability (\%) }\end{array}$ & Remarks & Study Authors \\
\hline $\begin{array}{c}\mathrm{Ti}_{3} \mathrm{C}_{2} \mathrm{~T}_{\mathrm{x}} \mathrm{NSs} / \mathrm{Au}- \\
\text { Pd NPs }\end{array}$ & $\begin{array}{c}\mathrm{SPE} / \mathrm{Ti}_{3} \mathrm{C}_{2} \mathrm{~T}_{\mathrm{x}} \\
\mathrm{NSs} / \mathrm{Au}- \\
\mathrm{Pd} / \mathrm{GA} / \mathrm{AChE}\end{array}$ & Amperometry & $\begin{array}{c}\text { Paraoxon/ } \\
\text { organophosphorus } \\
\text { pesticides }\end{array}$ & $\begin{array}{c}0.36-3634 \mathrm{nM} ; \\
\quad 6.36 \mathrm{pM}\end{array}$ & $\begin{array}{c}\text { Pear } \\
\text { Cucumber }\end{array}$ & $\begin{array}{c}91.15-111.02 \% \\
2.91-6.37 \% \\
87.93-110.82 \% \\
1.08-5.89 \%\end{array}$ & $\begin{array}{c}\text { Desired catalytic } \\
\text { activity; rapid; } \\
\text { superior conductivity } \\
\text { and stability }\end{array}$ & $\begin{array}{l}\text { Zhao et al. } \\
\text { (2018) [145] }\end{array}$ \\
\hline $\mathrm{YbMoSe}_{2}$ & $\mathrm{YbMoSe}_{2} / \mathrm{GCE}$ & DPV & $\begin{array}{l}\text { Diphenylamine/anti- } \\
\text { scald agent in } \\
\text { fruits }\end{array}$ & $\begin{array}{l}0.01-80 \mu \mathrm{M} ; \\
0.004 \mu \mathrm{M}\end{array}$ & Spiked pear fruits & $99-110 \% ; 2.09-2.34 \%$ & $\begin{array}{l}\text { Increased active sites } \\
\text { and decreased } \\
\text { bandgap; high } \\
\text { reproducibility, } \\
\text { stability, and selectivity }\end{array}$ & $\begin{array}{l}\text { Ramaraj et al. } \\
\text { (2019) [146] }\end{array}$ \\
\hline BP NSs & $\begin{array}{l}\text { Aptamer-BP } \\
\text { NSs/GCE }\end{array}$ & EIS & Patulin/mycotoxin & $\begin{array}{c}1 \times 10^{-3}-1 \mu \mathrm{M} ; 0.03 \\
\times 10^{-3} \mu \mathrm{M}\end{array}$ & Apple juice & $\begin{array}{l}97.3-104.6 \% \\
2.8-4.2 \%\end{array}$ & $\begin{array}{c}\text { Effective amplification } \\
\text { of biosensor's signal; } \\
\text { enhanced sensitivity; } \\
\text { more } \\
\text { time-consumption }\end{array}$ & $\begin{array}{l}\text { Xu et al. } \\
\text { (2019) [147] }\end{array}$ \\
\hline Au NPs-BP NSs & $\begin{array}{c}\text { Aptamer-Au NPs-BP } \\
\text { NSs/GCE }\end{array}$ & EIS & Patulin/mycotoxin & $\begin{array}{c}0.1 \times 10^{-3}-10 \mu \mathrm{M} \\
0.03 \times 10^{-3} \mu \mathrm{M}\end{array}$ & Apple juice & $\begin{array}{l}96.2-104.0 \% \\
2.4-3.8 \%\end{array}$ & $\begin{array}{c}\text { Effective amplification } \\
\text { of biosensor's signal; } \\
\text { enhanced sensitivity; } \\
\text { more } \\
\text { time-consumption }\end{array}$ & $\begin{array}{l}\text { Xu et al. } \\
\text { (2019) [147] }\end{array}$ \\
\hline
\end{tabular}

nd = no data available. 
Eissa et al. developed a graphene-based voltammeter immunosensor to identify okadaic acid (OA) in spiked crustacean tissue extracts [136]. Dinophysis and Prorocentrum, as the most ubiquitous known dinoflagellates, produce OA, a lipophilic marine biotoxin, and accumulate it in shellfish [148]. When human beings consume OA-contaminated shellfish, OA inhibits protein phosphatase, such as PP1 and PP2A at the molecular level, and consequently causes a severe toxic effect known as diarrhetic shellfish poisoning [149-151]. Furthermore, it causes gastroabdominal disturbances, including vomiting, nausea, and diarrhea [152]. OA's maximum limitation level in mussels is $160 \mu^{\mathrm{g} \mathrm{kg}}{ }^{-1}$ (EC no. 853/2004 15) [153-155]. To detect OA, they functionalized graphene-modified screen-printed carbon electrodes (GSPE) by electrochemical reduction of 4-carboxyphenyldiazonium salts in an acidic aqueous solution. Then, the OA was covalently bonded to the electrode surface using carbodiimide chemistry. The developed graphene-based immunosensor had a detection limit of OA $19 \mathrm{ng} \mathrm{L}^{-1}$ in PBS buffer, which is much lower than OA's maximum limitation level in shellfish. The proposed electrochemical approach is a single-step and fast method to detect okadaic acid without using enzyme labeling and reduces both the assay's cost and time. Further, this sensor works on a direct competitive assay to prove its specificity and sensitivity and has been validated using certified reference mussel samples showing good recovery\%.

Soares et al. developed label-free laser-guided graphene (LIG) electrode functionalized with an antibody to electrochemically quantify the food-borne pathogen Salmonella enterica serovar Typhimurium [137]. According to data from the U.S. Food and Drug Administration (FDA) and the Centers for Disease Control and Prevention (CDC), Salmonella enterica is one of the leading causes of food-borne illness, which causes approximately 1.2 million illnesses and 450 deaths each year in the United States [156]. The LIG biosensors detected live Salmonella species in chicken broth at a linear range of 25 to $10^{5} \mathrm{CFU} \mathrm{mL}^{-1}$ with a low detection limit of $13 \pm 7 \mathrm{CFU} \mathrm{mL}{ }^{-1}$. Figure 4 showed the fabrication, functionalization, and sensing potential of the sensor against bacterial microbes schematically. The advantages of this sensor are low cost and disposable. It can be applied to in-field food processing facilities to trace the contaminants, crucial for successful commercialization. The shelf life of freeze-dried $\left(-20^{\circ} \mathrm{C}\right)$ immunosensors has been reported to be seven days. The estimated cost of the developed sensor is inexpensive, with $\$ 1.76$ per device.

Some algae species, including Ptychodiscus brevis, produce BTX-2 (brevetoxin B) which results in neurotoxic shellfish poisoning (NSP) by consuming BTX-2 contaminated shellfish $[157,158]$. To detect brevetoxin B (BTX-2) in seafood, Tang et al. devised a practicable and straightforward magneto-controlled immunosensing platform. In this platform, guanine-assembled graphene nanoribbons (GGNR) were used as molecular tags on magnetic carbon paste electrodes. Monoclonal mouse anti-BTX-2 antibody was covalently bound to the electrode surface. The chemically modified bovine serum albumin-BTX-2 conjugated (BTX-2-BSA) with the GGNRs acts as the recognition elements. Under optimal conditions, the magneto-controlled immunosensor showed a dynamic concentration range at $1.0 \mathrm{pg} \mathrm{mL}^{-1}$ to $10 \mathrm{ng} \mathrm{mL}^{-1}$ of BTX-2. [138]. When this chemical immunoassay was carried out for 12 spiked samples with Musculista senhousia, Sinonovacula constricta, and Tegillarca granosa comparing with the commercialized ELISA method, there was no significant differences found between them, which proves the reliability and potential of the proposed immunosensor.

Bulbul et al. studied a non-enzymatic nanocatalyst approach to construct an electrochemical aptasensor that involves the contribution of nanoceria (nCe) tag and $\mathrm{GO}$ for the detection of Ochratoxin A (OTA) in corn samples [139]. The nCe labeled target analyte was captured by the immobilized aptamer on the GO modified electrode's surface. The electrochemical signal was generated by the redox reaction between the species and the nCe tag. Subsequently, the GO layer amplified the signal increasing the sensitivity of the assay. The aptasensor showed a linear response to OTA in the range of $0.15-180 \mathrm{nM}$ with a detection limit of $0.1 \mathrm{nM}$ under optimal conditions. The reported biosensor found an enhancement in the target analyte's sensitivity as the immobilized aptamer captures nCe 
labeled targets distinguishing them from non-label targets. The literature reports reveal that filamentous fungi of Aspergillus and Penicillium produce OTA. This low molecular weight mycotoxin is known to contaminate various food items, including dried fruits, cereals, cocoa, spices, beer, and wine [159]. The International Agency for Research on Cancer (Group 2B) informed that OTA contributes to cancer development being nephrotoxic, teratogenic, and immunosuppressive [160]. The European Union has stated that the regulatory limits for OTA in raw cereal grains, dried fruits, coffee products, and grape juice are $5 \mu \mathrm{g} \mathrm{kg}^{-1}$, $10 \mu \mathrm{g} \mathrm{kg}^{-1}, 5 \mu \mathrm{g} \mathrm{kg}^{-1}$, and $2 \mu \mathrm{g} \mathrm{kg}^{-1}$, respectively (EC no. 123/2005) [139,161]. Wang et al. developed an electrochemical-assisted desorption method for the solid-phase extraction of metal ions $\left(\mathrm{Pb}^{2+}\right)$ in tap water, mineral water, and beverage [140]. An array-like polyaniline nanofiber synthesized on the surface of graphene oxide (polyaniline-GO) acted as a well-ordered conducting sorbent. The adsorption/desorption process was accompanied by the changes of the as-prepared sorbent in cyclic voltammetry. The limit of detection was found as $0.04 \mu \mathrm{g} \mathrm{L}^{-1}$ under the optimal $\mathrm{pH}$ value. The proposed electrochemically assisted desorption method is simple, cost-effective, rapid, and eco-friendly and highlights that it does not require any elution to elute the target analyte. The sensor displays good anti-interference properties across various interference ions and has the potential to extract the target-analyte in the field of food safety control. Heavy metal ions, especially lead, are toxic and carcinogenic to the human body [162]. The World Health Organization has established a limit of $10 \mu \mathrm{g} \mathrm{L}^{-1}$ for $\mathrm{Pb}^{2+}$ ions in drinking water. According to the Environmental Protection Agency, the maximum criteria for $\mathrm{Pb}^{2+}$ ions in fresh water and saltwater were $65 \mu \mathrm{g} \mathrm{L}^{-1}$ and $210 \mu \mathrm{g} \mathrm{L}^{-1}$, respectively $[140,163]$.

(A)

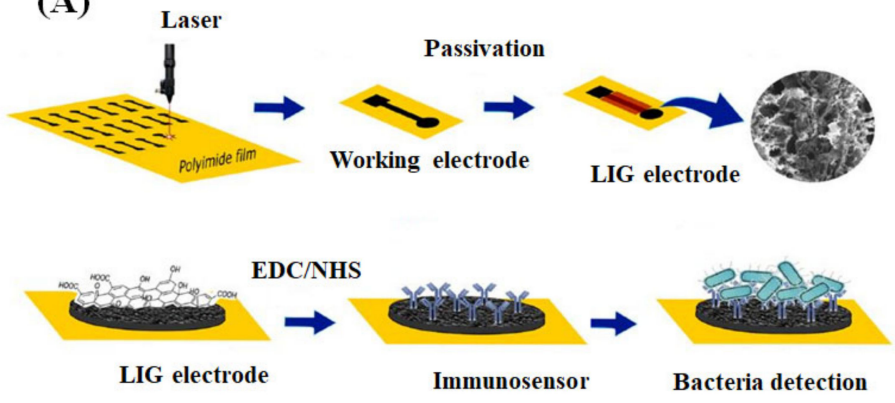

(C)

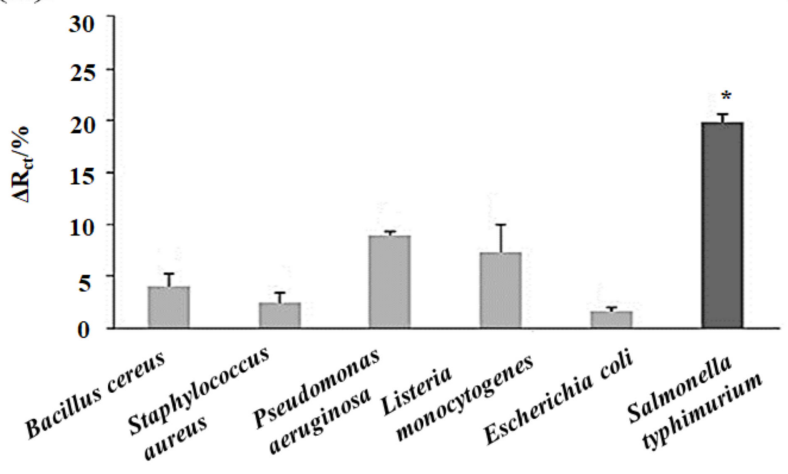

(B)

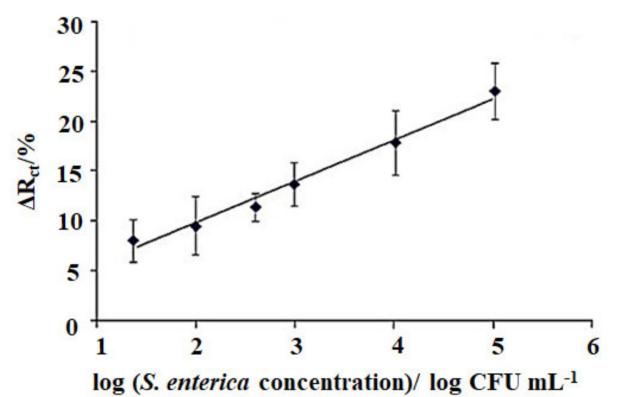

(D)

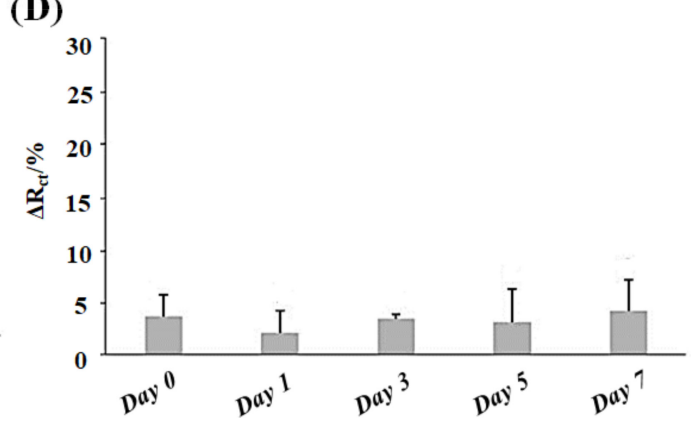

Figure 4. (A) Schematic demonstration of fabrication, biofunctionalization, and sensing of the LIG immunosensor. LIG is processed onto a polyimide sheet to create the working electrode, and subsequently, the electrode is passivated with lacquer. SEM image of the LIG surface is shown. The Salmonella antibodies are immobilized on the working electrode via carbodiimide cross-linking chemistry (EDC/NHS) to detect Salmonella microbes. (B) The linear calibration curve of charge transfer resistance change $\left(\Delta \mathrm{R}_{\mathrm{ct}}\right)$ vs. S. enterica concentrations (generated from Nyquist plots of impedance spectra) in chicken broth. (C) $\Delta \mathrm{R}_{\mathrm{ct}}$ vs. different interferent bacterial species $\left(10^{4} \mathrm{CFU} \mathrm{mL} \mathrm{m}^{-1}\right)$ to show the specificity of the immunosensor. (D) Shelf-life test to investigate the stability of the immunosensors for seven days. All the data shown as mean $\pm \mathrm{SD}, n=3 .{ }^{*}$ means significantly difference $(p<0.05)$ [137]. 
Mohammad-Razdari et al. developed a promising electrochemical method using an impedimetric aptasensor based AuNPs/rGO nanocomposite-modified pencil graphite electrode for the detection of tetracycline (TET) in milk samples with high reproducibility [141]. Gold nanoparticles (AuNPs) are widely used in electrochemical biosensors owing to their excellent electrical conductivity and catalytic property $[164,165]$. The combination of rGO and AuNPs makes the composite increase the electron transfer rate on the electrode surface and provide self-assembling sites for the aptamer DNA segment. While recording the transfer resistance, $\Delta \mathrm{R}_{\mathrm{ct}}\left(\mathrm{R}_{\mathrm{ct}}\right.$ before and after aptamer) of various antibiotics, such as TET, streptomycin, penicillin G, and sulfadiazine, the results revealed that the sensor is more sensitive towards TET. This impedimetric biosensor is a promising method for the quantitative and qualitative measurement of TET in milk samples. The sensor is potentially employed in the early screening of milk samples, demonstrating a high reproducibility and stability (21 days). Further, the sensor can detect other antibiotics in various food items, including shrimp, meat, and fish. TET is commonly used to treat infectious diseases, like mastitis [166]. There are more possibilities to contaminate the food products like milk, eggs, meat, and chicken when the antibiotic is overused as an antibacterial and growth enhancer in veterinary medicine [167]. Consumption of such contaminated food items causes increased drug resistance in the human body [168]. The European Union has established the maximum residue level of TET in milk, meat, and eggs to be 220, 220 and $440 \mathrm{nM}$, respectively [169]. Hence, the quantitative measurement of TET in milk samples using a sensitive method becomes essential to protect human health.

Imidacloprid (IDP), a typical neonicotinoid, is commonly used to control agricultural pests such as whiteflies, lepidoptera, and beetles and is one of the most used insecticides worldwide $[170,171]$. However, when a large quantity of IDT is absorbed by both vertebrates and invertebrates in the environment, the IDP residues cause a significant health risk to humans [172]. Zhao et al. fabricated an electrochemically reduced graphene oxide/cyclodextrin/glassy carbon electrode (E-rGO/CD/GCE) composite system for the detection of imidacloprid (IDP) residues in brown rice [142]. Initially, the complex of $\mathrm{GO} / \mathrm{CDs}$ was prepared by simple stirring, and subsequently, GCE was modified using the complex by a drop-casting method. The oxygen-containing functional groups in $\mathrm{GO}$ were removed by an electrochemical reduction in PBS to obtain the desired electrochemically reduced composite system, as shown in Figure 5 . To acquire the best signaling performance, they used three types of cyclodextrins $(\alpha-, \beta-, \gamma-C D)$ for analyzing sensor performance and found that $\alpha$-CD had the best signal amplification for IDP. The developed sensor possessed long-term stability indicated by a more comprehensive linear range $(0.5-40 \mu \mathrm{M})$ and a low detection limit $(0.02 \mu \mathrm{M})$. The developed electrochemical sensor has advantageous properties, such as outstanding sensitivity, selectivity, stability, and reproducibility. The electrode fabrication via an electrochemical reduction approach is cost-effective and less time-consuming than the wet-chemical synthesis.

Chan et al. presented an $\mathrm{rGO} / \mathrm{Au}$ electrode-based biosensor to detect botulinum neurotoxin serotype A light chain (BoNT-LcA) protease activity in milk samples [143]. The synaptosomal-associated protein 25-green fluorescent protein (SNAP-25-GFP) substrate was immobilized on the fabricated $\mathrm{rGO} / \mathrm{Au}$ surface via a pyrenebutyric acid linker. BoNTLcA cuts SNAP-25-GFP precisely at the cleavage sites to release the cut section from the electrode surface, detected by differential pulse voltammetry (DPV) (Figure 6). Though the proposed sensor witnessed the increased sensitivity, it had the drawback of non-specific adsorption of proteins in milk. The sensor was washed with Tween-20 after sample incubation to avoid other proteins' interference in samples and the unwanted cleavage of SNAP-25-GFP. BoNT is a lethal neurotoxin secreted by Clostridium botulinum and can cause fatal paralytic illness botulism even in its low dose [173]. The researchers have identified seven serotypes (A-G) of botulinum toxins so far. Among them, BoNT/A has been reported to cause fatal food-borne botulism in human beings [174]. BoNT/A consists of a heavy chain and a light chain (LcA); however, the specific cleavage of SNAP-25 peptide is occurred by the LcA being responsible for the potential neurotoxicity [175]. 
Poo-arporn et al. developed a new disposable electrochemical sensor using a magnetic screen-printed electrode (MSPE) for the identification of ractopamine (RAC) in spiked real pork samples [144]. The electrode was modified with an iron oxide magnetic nanoparticle doping on reduced graphene oxide $\left(\mathrm{Fe}_{3} \mathrm{O}_{4} / \mathrm{rGO}\right)$ that promotes the electron transfer and raises the sensor's sensitivity. The results of DPV showed a linear concentration range of $0.05-10 \mu \mathrm{M}$ and $10-100 \mu \mathrm{M}$ with a detection limit of $13 \mathrm{nM}$. The nanocomposite $\mathrm{Fe}_{3} \mathrm{O}_{4} / \mathrm{rGO}$ has promoted electron transfer, enhancing the sensitivity of the developed sensor. Further, the sensor is disposable and portable, with good reproducibility in onsite and real-time electroanalysis of the spiked pork samples. RAC is a $\beta$-adrenergic agonist, originally used to treat ailments including pulmonary disease and asthma [176]. Meanwhile, it has been illegally utilized as animal feed to reduce body fat deposition and improve protein accumulation [177]. Though the European Union has forbidden the employment of RAC in daily animal feeds, many countries, including China, are still allowing $[178,179]$. The drug residues accumulated in animal tissues can endanger consumer health, exhibiting symptoms such as cardiac palpitations, nervousness, muscular tremors, and tachypnea [180,181].
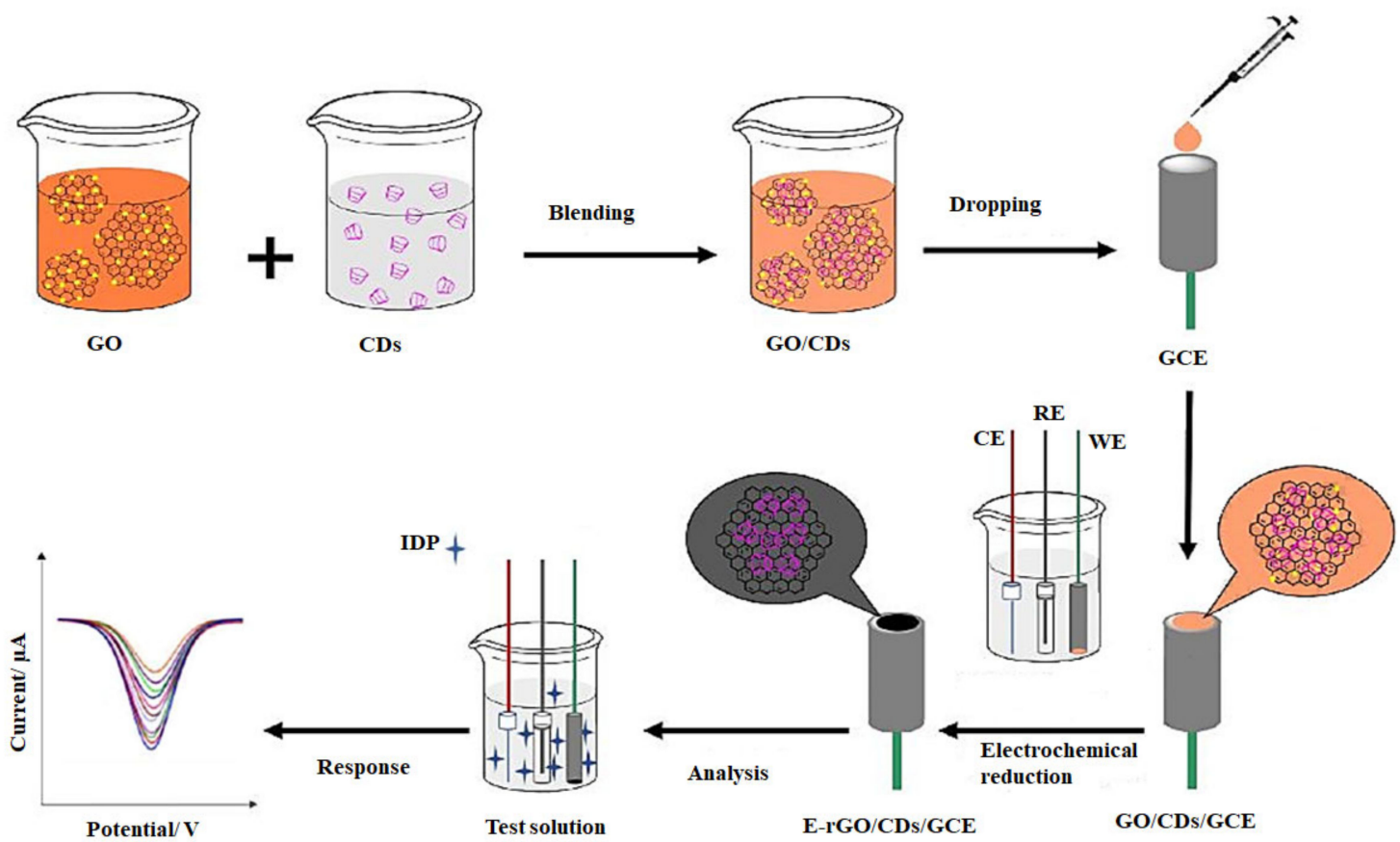

Figure 5. Schematic diagram demonstrating the preparation of food detection system containing electrochemically reduced graphene oxide/cyclodextrin modified glassy carbon electrode (E-rGO/CDs/GCE) to quantify the amount of imidacloprid (IDP) in test solution [142]. CE-counter electrode, RE-reference electrode, and WE-working electrode.

Zhao et al. proposed a disposable electrochemical biosensor $\left(\mathrm{Ti}_{3} \mathrm{C}_{2} \mathrm{~T}_{\mathrm{x}} \mathrm{NSs} / \mathrm{Au}-\mathrm{Pd}\right)$ to detect paraoxon organophosphorus pesticide in pear and cucumber samples [145]. The biosensor detected paraoxon with a linear concentration of $0.1-1000 \mu \mathrm{g} \mathrm{L}^{-1}$ and a low detection limit of $1.75 \mathrm{ng} \mathrm{L}^{-1}$. This enzymatic biosensor rapidly detects OPs exploiting superior conductivity and stability from the composite, MXene/Au-Pd. The screen-printed electrode (SPE) is disposable, and the nanoparticles ( $\mathrm{Au}-\mathrm{Pd}$ ) are shape-controlled with desired catalytic activity. Organophosphorus pesticides (OPs) are compounds containing phosphorus elements, which control pests, plant diseases, and parasitic weeds [182,183]. When OPs are oxidized into highly toxic compounds, they cause more significant human health threats than the original compounds [145,184]. Ramaraj et al. developed a means to detect diphenylamine (DPA) in spike pear fruit by studying the electrocatalytic activity of $\mathrm{YbMoSe}_{2}$ modified glassy carbon electrodes ( $\mathrm{YbMoSe}_{2} / \mathrm{GCE}$ ) [146]. A high level of electrochemical activity of $\mathrm{YbMoSe}_{2} / \mathrm{GCE}$ was demonstrated with a low detection limit 
of $0.004 \mu \mathrm{M}$ (Figure 7). DPA, a colorless aniline derivative, is used as a post-harvest antiscald agent to prevent the decomposition of apples and pears during storage. Meanwhile, excessive consumption of DPA causes severe health issues to humans, such as bladder diseases, red blood cell damage, and hypertension $[185,186]$. Therefore, the European Union has proposed the daily acceptable level of DPA in fruits of about $10 \mathrm{mg} \mathrm{kg}^{-1}$ for pears and $5 \mathrm{mg} \mathrm{kg}^{-1}$ for apples $[187,188]$. The incorporation of $\mathrm{Yb}^{\prime}$ 's heterogeneous spin with $\mathrm{MoSe}_{2}$ generated the lattice distortion increasing the active sites, which helped for the high level of reproducibility, selectivity, and stability during the detection of targetanalyte (DPA). The decreasing bandgap enabled an exceptional electronic conductivity and electrochemical activity in the proposed biosensor.

(A)

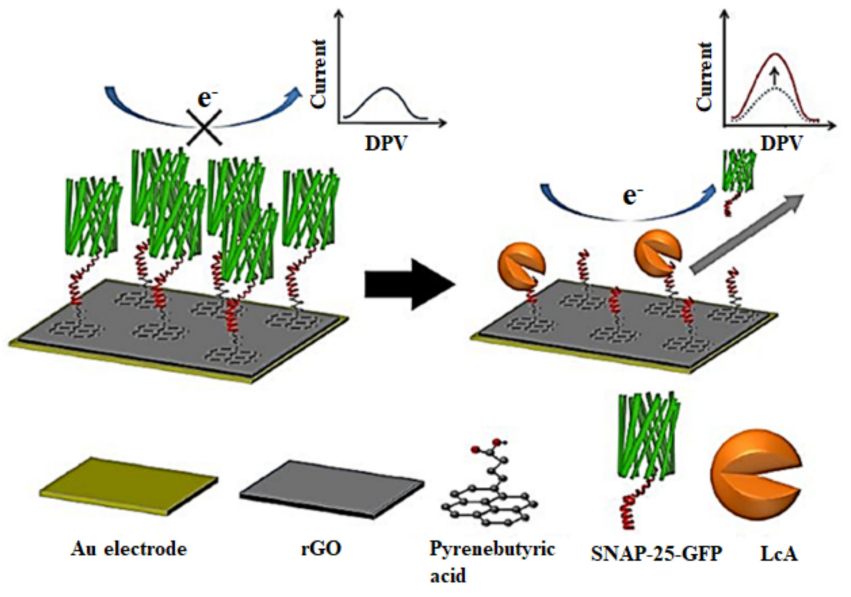

(D)

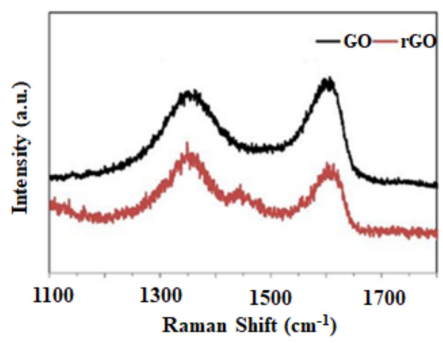

(E)

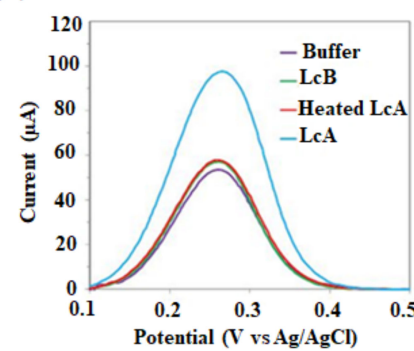

(B)

(C)
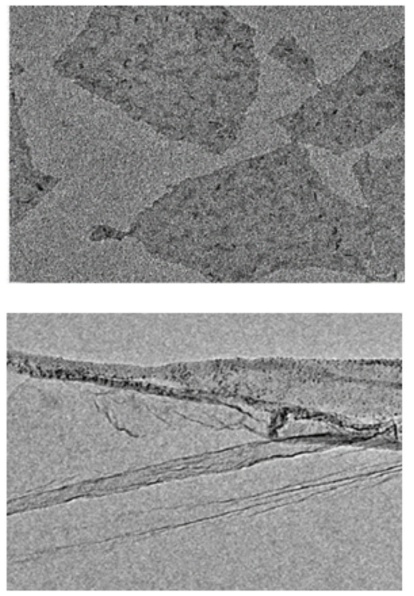

(F)

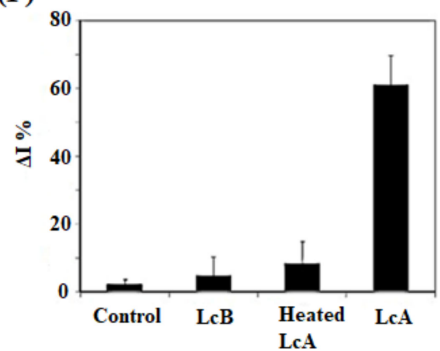

Figure 6. (A) Schematic diagram illustrating the detection mechanism of an rGO-based biosensor. SNAP-25-GFP peptide is immobilized on the rGO surface, which is previously conjugated with pyrenebutyric acid. The target BoNT-LcAs specifically cleave SNAP-25-GFP molecules, detaching them from $\mathrm{rGO} / \mathrm{Au}$ electrode surface. The detection of enzymatic activity decreases the hindrance of redox probes transfer on electrodes resulting in increased electrochemical currents. (B) TEM image of rGO flakes and (C) rGO sheets with ripples and wrinkles. (D) Raman spectra of GO and rGO. (E) Specificity testing of control buffer and fresh BoNT-LcA, heated BoNT-LcA, and fresh BoNT-LcA at the concentration of $1 \mathrm{ng} \mathrm{mL}^{-1}$. (F) Relative DPV peak current change $(\Delta \mathrm{I} \%)$ for the same samples [143].

Xu et al. modified a glassy carbon electrode with black phosphorus nanosheets (BP NSs) and an aptamer to identify mycotoxin patulin (PAT) in spiked food samples [147]. The impedimetric assay measured PAT over a linear range from $1.0 \mathrm{nM}$ to $1.0 \mu \mathrm{M}$ with a detection limit of $0.3 \mathrm{nM}$. The electrode was further modified with gold nanoparticles to improve the sensor's performance, which showed a more comprehensive linear range of $0.1 \mathrm{nM}$ to $10.0 \mu \mathrm{M}$ and a low detection limit of $0.03 \mathrm{nM}$. The larger surface area of BP NSs increased the loading of AuNP and aptamers on the electrode surface, effectively amplifying the biosensor's signal. The AuNPs provided the anchoring sites of the aptamer to enhance the sensor's efficiency of electron transport. However, the method had more time-consumption for the preparation of nanomaterials and the modification of electrodes. Some fungi, including Aspergillus, Penicillium, and Byssochlamys, produce patulin (4-hydroxy-4H-furo[3,2-c] 
pyran-2[6H]-one) as a secondary mycotoxin product $[189,190]$. The regulation by The Joint Food and Agriculture Organization/World Health Organization Expert Committee on Food Additives has determined the maximum daily level of PAT is $0.4 \mu \mathrm{g} \mathrm{kg}^{-1}$ by body weight [191].

(A)

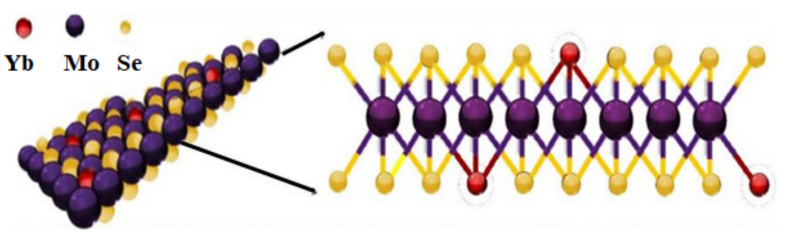

(B)

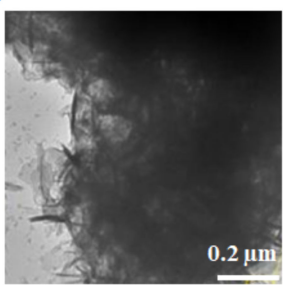

(C)

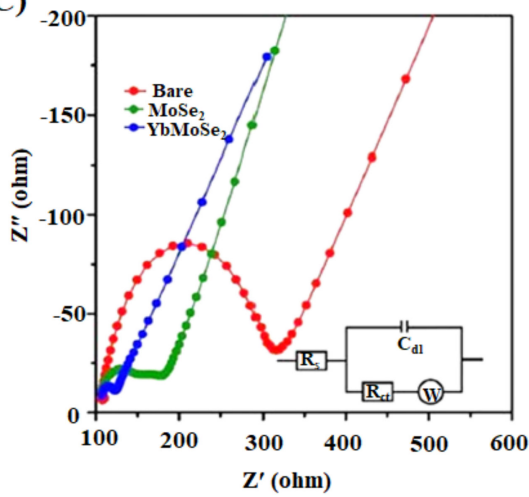

(D)

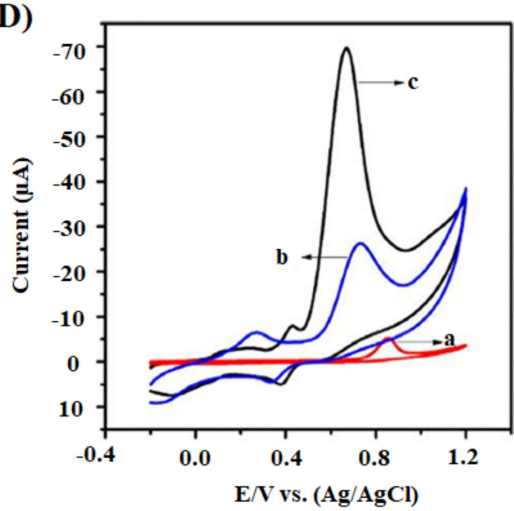

Figure 7. (A) Schematic of the proposed molecular packing structure and (B) HRTEM image of $\mathrm{YbMoSe}_{2}$. (C) Nyquist plot demonstrating the electrochemical performance of bare, $\mathrm{MoSe}_{2}$, and $\mathrm{YbMoSe}_{2}$ glassy carbon electrodes in $5 \mathrm{mM}$ ferricyanide system in $0.1 \mathrm{M}$ of $\mathrm{KCl}$. The inset shows an equivalent circuit model $\left(\mathrm{R}_{\mathrm{ct}}\right.$-charge transfer resistance; $\mathrm{C}_{\mathrm{dl}}$-double-layer capacitance; $\mathrm{R}_{\mathrm{s}}$-solution resistance; W-Warburg impedance). (D) CV of bare GCE (a), MoSe 2 /GCE (b), and $\mathrm{YbMoSe}_{2} / \mathrm{GCE}$ (c) with $0.29 \mathrm{mM}$ diphenylamine in $\mathrm{N}_{2}$ purged buffer at $50 \mathrm{mV} \mathrm{s}^{-1}$ [146].

\section{Recent Advancements in Biosensors to Analyze the Food Toxicants}

The potential revolution in consumer, healthcare, and manufacturing testing has made the global biosensor market worth over 10 billion dollars per annum and has been a burgeoning field of interdisciplinary research. However, an important barrier to biosensors' widespread marketing is their cost, although many systems have been validated and proven at the concept level in the laboratory setting [192]. As there is downward pressure on costs, researchers are keen on developing different biosensors, such as multianalyte, flexible, hand-held, or computerized biosensors, without compromising their sensitivity and specificity [193]. This section is pertinent to all types of nanoparticles-based electrochemical biosensors but not limited to 2D nanomaterials-based sensors.

Regenerating biosensors is a recent technique to develop multianalyte biosensors enabling their reuse and reducing the cost per test. Regeneration has been achieved in amperometric and potentiometric sensors by overcoming the analyte and bioreceptor's attractive forces. The contribution of enthalpy and entropy must be considered in thermodynamics, and the forces in the solvent environment can be altered using a regeneration buffer. The essential criteria for the successful regeneration of a biosensor are as follows: The signal loss between the interrogation cycles must be less than $5 \%$ showing the signal loss profile linear for accurate calibration, and more than 10 continual cycles must be achieved in restoring the baseline signal to $< \pm 5 \%$ [194].

The development of hand-held devices connected with packing materials has enabled monitoring food quality throughout the entire supply chain and reported food spoilage possible to the consumers in commercial places such as supermarkets [195]. Hand-held 
devices, such as smartphones, are practical compact systems in conducting real-time testing. It is predicted that the usage of smartphones worldwide will increase by $58 \%$ from 2016 to 2022 [196]. The implementation of a piece of software into smartphones can be correlated with cellphones' imaging capacity. When the biosensors analyze the food toxicants, the smartphones will gather the data and process them into readable information for the consumers. Flexible biosensors are being developed as wearable devices, such as smart wristbands, for emerging disposable biosensing applications. The wristband comprises a small battery, a flexible sensor array, and a flexible printed circuit board [197]. Consumers are using these kinds of biosensors for health monitoring. The same technique can be applied to in situ detection and long-term monitoring of toxic analytes in the food industry.

\section{Conclusions}

In the present review, we have discussed the recent development of 2D nanomaterialbased electrochemical biosensors in analyzing food toxicants. The studies have exposed 2D nanocomposites' electrochemical analytical efficiency encompassing their sensitivity with a wide linear range and limit of detection and their real sample application with the salient findings of recovery and repeatability. Electrochemical biosensors provide sensitive qualitative and quantitative measurements of the analytes. The methods developed are inexpensive and time-saving compared with traditional analytical methods. These sensors involve in real-time and highly selective analyses without pre-concentration steps in many cases. Although these kinds of biosensors display remarkable advantages over traditional methods, there are still many difficulties developing a perfect biosensing technique to make them commercialized quickly: (1) Except for graphene family nanomaterials, only a few reports are available based on graphene-like 2D nanomaterials-based electrochemical food sensors. (2) The physicochemical properties of 2D nanomaterials play a pivotal role in determining their biosensing ability. But, in many kinds of literature, the researchers have failed to provide the parameters such as size and lateral thickness of the nanomaterials. (3) A comparative study in food toxic analysis among the 2D nanomaterials or with other dimensional nanomaterials should be carried out to bring out more effective compounds in the field. (4) The concentration of nanoparticles should be optimized to know the point at which the desired analytes attain saturation level during analysis. (5) Though electrochemical biosensors found advancement to detect food analytes with higher sensitivity, the analyte's residence time with the electrochemical interface is still questionable. (6) The biological interaction of the analytes with various $2 \mathrm{D}$ nanomaterials should be discussed. The following comments can be suggested for future directions in this field: (1) Analyzing the electrochemical sensing potential of 2D nanomaterials following the thorough study of electrical conductivity, electrochemical conversion capability, and biomolecule immobilization capacity, dependent on size, shape, morphology, and defects of the nanoparticles. (2) Performing computational studies to have a deep insight into molecular interaction of food toxicants with 2D nanomaterials. (3) Determining 2D nanomaterial's preferential selectivity with the similarly classified but differently molecular structured food toxicants. (4) Developing electrochemical sensors with microfluidics, microelectrode arrays, signal amplification, magnetic filtration, and antibody design to improve the target's sensitivity and selectivity. (5) Achieving many more inexpensive and long storage devices without compromising the accuracy of the analysis. We hope that the researchers with interdisciplinary backgrounds will advance the field of electrochemical food sensors by signifying the importance of 2D nanomaterials considering the associated problems and the concerning suggestions.

Author Contributions: I.S.R. developed the idea and structure of the review article. I.S.R., M.V., and C.K. wrote the manuscript collecting the materials from D.R.P., J.H.L. and D.W.H. revised and improved the manuscript. J.H.L. and D.W.H. supervised the manuscript. All authors have read and agreed to the published version of the manuscript. 
Funding: This work was supported by the National Research Foundation of Korea (NRF) grant funded by the Korean government (MSIT) (grant no. 2019R1A4A1024116) and by Basic Science Research Program through the NRF of Korea funded by the Ministry of Education (no. 2018R1D1A1B07049077).

Institutional Review Board Statement: Not applicable.

Informed Consent Statement: Not applicable.

Data Availability Statement: No new data were created or analyzed in this study. Data sharing is not applicable to this article.

Conflicts of Interest: The authors declare no conflict of interest.

$\begin{array}{ll}\text { Abbreviations } \\ \text { GCE } & \text { Glassy carbon electrode } \\ \text { SPE } & \text { Screen-printed electrodes } \\ \text { GSPE } & \text { Graphene modified screen-printed carbon electrode } \\ \text { PGE } & \text { Pencil graphite electrode } \\ \text { MSPE } & \text { Magnetic screen-printed electrode } \\ \text { LIG } & \text { Laser-induced graphene } \\ \text { EIS } & \text { Electrochemical impedance spectroscopy } \\ \text { LSV } & \text { Linear sweep voltammetry } \\ \text { DPV } & \text { Differential pulse voltammetry } \\ \text { CV } & \text { Cyclic voltammetry } \\ \text { SWV } & \text { Square wave voltammetry } \\ \text { FAAS } & \text { Flame atomic absorption spectrometry } \\ \text { BP NSs } & \text { Black phosphorus nanosheets } \\ \text { GO } & \text { Graphene oxide } \\ \text { rGO } & \text { Reduced graphene oxide } \\ \mathrm{Ti}_{3} \mathrm{C}_{2} \mathrm{~T}_{\mathrm{x}} & \text { Titanium carbide MXene nanosheets } \\ \text { YbMoSe } & \text { Ytterbium-doped molybdenum selenide } \\ \text { Fe }{ }_{3} \mathrm{O}_{4} & \text { Iron oxide } \\ \mathrm{AChE} & \text { Acetylcholinesterase } \\ \mathrm{Au}-\mathrm{Pd} & \text { Gold-palladium } \\ \mathrm{CFU} & \text { Colony forming unit } \\ \mathrm{EDC} & \text { 1-(3-Dimethylaminopropyl)-3-ethylcarbodiimide hydrochloride } \\ \mathrm{SNAP-25} & \text { Synaptosomal-associated protein-25 } \\ \mathrm{GFP} & \text { Green fluorescent protein } \\ \mathrm{BSA} & \text { Bovine serum albumin } \\ & \end{array}$

\section{References}

1. Sozer, N.; Kokini, J.L. Nanotechnology and its applications in the food sector. Trends Biotechnol. 2009, 27, 82-89. [CrossRef]

2. Chaudhry, Q.; Scotter, M.; Blackburn, J.; Ross, B.; Boxall, A.; Castle, L.; Aitken, R.; Watkins, R. Applications and implications of nanotechnologies for the food sector. Food Addit. Contam. Part A Chem. Anal. Control. Expo. Risk Assess. 2008, 25, 241-258. [CrossRef]

3. Singleton, V.L. Naturally occurring food toxicants: Phenolic substances of plant origin common in foods. Adv. Food Res. 1981, 27, 149-242. [CrossRef]

4. Unnevehr, L.J. Food safety issues and fresh food product exports from LDCs. Handb. Agric. Econ. 2000, 23, 231-240. [CrossRef]

5. McLaughlin, M.J.; Parker, D.R.; Clarke, J.M. Metals and micronutrients-Food safety issues. Field Crops Res. 1999, 60, 143-163. [CrossRef]

6. Kuiper, H.A.; Kleter, G.A.; Noteborn, H.P.; Kok, E.J. Assessment of the food safety issues related to genetically modified foods. Plant J. 2001, 27, 503-528. [CrossRef]

7. Kuiper, H.A.; Kok, E.J.; Engel, K.H. Exploitation of molecular profiling techniques for GM food safety assessment. Curr. Opin. Biotechnol. 2003, 14, 238-243. [CrossRef]

8. Nishi, K.; Isobe, S.; Zhu, Y.; Kiyama, R. Fluorescence-based bioassays for the detection and evaluation of food materials. Sensors 2015, 15, 25831-25867. [CrossRef] [PubMed]

9. Yan, E.L.; Ortiz, D.; Calderón, J.; Batres, L.; Carrizales, L.; Mejía, J.; Martínez, L.; García-Nieto, E.; Díaz-Barriga, F. Overview of human health and chemical mixtures: Problems facing developing countries. Environ. Health Perspect. 2002, 110 (Suppl. 6), 901-909. [CrossRef] [PubMed] 
10. Bülbül, G.; Hayat, A.; Andreescu, S. Portable nanoparticle-based sensors for food safety assessment. Sensors 2015, 15, 30736-30758. [CrossRef] [PubMed]

11. Steil, D.; Pohlentz, G.; Legros, N.; Mormann, M.; Mellmann, A.; Karch, H.; Müthing, J. Combining mass spectrometry, surface acoustic wave interaction analysis, and cell viability assays for characterization of shiga toxin subtypes of pathogenic escherichia coli bacteria. Anal. Chem. 2018, 90, 8989-8997. [CrossRef] [PubMed]

12. García-Galán, M.J.; Silvia Díaz-Cruz, M.; Barceló, D.; Barceló, D. Combining chemical analysis and ecotoxicity to determine environmental exposure and to assess risk from sulfonamides. Trends Analyt. Chem. 2009, 28, 804-819. [CrossRef]

13. Li, Z.; Li, X.; Jian, M.; Geleta, G.S.; Wang, Z. Two-dimensional layered nanomaterial-based electrochemical biosensors for detecting microbial toxins. Toxins 2020, 12, 20. [CrossRef]

14. Man, Y.; Liang, G.; Li, A.; Pan, L. Analytical methods for the determination of alternaria mycotoxins. Chromatographia 2017, 80, 1-14. [CrossRef]

15. Richardson, S.D.; Ternes, T.A. Water analysis: Emerging contaminants and current issues. Anal. Chem. 2018, 90, 398-428. [CrossRef]

16. Patel, P.D. (Bio)sensors for measurement of analytes implicated in food safety: A review. Trends Anal. Chem. 2002, 21, 96-115. [CrossRef]

17. Van Dorst, B.; Mehta, J.; Bekaert, K.; Rouah-Martin, E.; De Coen, W.; Dubruel, P.; Blust, R.; Robbens, J. Recent advances in recognition elements of food and environmental biosensors: A review. Biosens. Bioelectron. 2010, 26, 1178-1194. [CrossRef] [PubMed]

18. Farabullini, F.; Lucarelli, F.; Palchetti, I.; Marrazza, G.; Mascini, M. Disposable electrochemical genosensor for the simultaneous analysis of different bacterial food contaminants. Biosens. Bioelectron. 2007, 22, 1544-1549. [CrossRef]

19. McGrath, T.F.; Elliott, C.T.; Fodey, T.L. Biosensors for the analysis of microbiological and chemical contaminants in food. Anal. Bioanal. Chem. 2012, 403, 75-92. [CrossRef] [PubMed]

20. Reverté, L.; Prieto-Simón, B.; Campàs, M. New advances in electrochemical biosensors for the detection of toxins: Nanomaterials, magnetic beads and microfluidics systems. A review. Anal. Chim. Acta 2016, 908, 8-21. [CrossRef]

21. Gan, X.; Zhao, H.; Quan, X. Two-dimensional MoS2: A promising building block for biosensors. Biosens. Bioelectron. 2017, 89, 56-71. [CrossRef] [PubMed]

22. Goud, K.Y.; Kailasa, S.K.; Kumar, V.; Tsang, Y.F.; Lee, S.E.; Gobi, K.V.; Kim, K.-H. Progress on nanostructured electrochemical sensors and their recognition elements for detection of mycotoxins: A review. Biosens. Bioelectron. 2018, 121, 205-222. [CrossRef]

23. Singh, T.; Shukla, S.; Kumar, P.; Wahla, V.; Bajpai, V.K.; Rather, I.A. Application of nanotechnology in food science: Perception and overview. Front. Microbiol. 2017, 8. [CrossRef]

24. Yu, H.; Park, J.-Y.; Kwon, C.W.; Hong, S.-C.; Park, K.-M.; Chang, P.-S. An overview of nanotechnology in food science: Preparative methods, practical applications, and safety. J. Chem. 2018, 2018, 5427978. [CrossRef]

25. Morris, V.J. Emerging roles of engineered nanomaterials in the food industry. Trends Biotechnol. 2011, 29, 509-516. [CrossRef]

26. Hayat, A.; Marty, J.L. Disposable screen printed electrochemical sensors: Tools for environmental monitoring. Sensors 2014, 14, 10432-10453. [CrossRef]

27. Yang, Y.; Asiri, A.M.; Du, D.; Lin, Y. Acetylcholinesterase biosensor based on a gold nanoparticle-polypyrrole-reduced graphene oxide nanocomposite modified electrode for the amperometric detection of organophosphorus pesticides. Analyst 2014, 139, 3055-3060. [CrossRef] [PubMed]

28. Pan, D.; Gu, Y.; Lan, H.; Sun, Y.; Gao, H. Functional graphene-gold nano-composite fabricated electrochemical biosensor for direct and rapid detection of bisphenol A. Anal. Chim. Acta 2015, 853, 297-302. [CrossRef] [PubMed]

29. Liu, W.; Ullah, B.; Kuo, C.-C.; Cai, X. Two-dimensional nanomaterials-based polymer composites: Fabrication and energy storage applications. Adv. Polym. Technol. 2019, 2019, 4294306. [CrossRef]

30. Fiori, G.; Bonaccorso, F.; Iannaccone, G.; Palacios, T.; Neumaier, D.; Seabaugh, A.; Banerjee, S.K.; Colombo, L. Electronics based on two-dimensional materials. Nat. Nanotechnol. 2014, 9, 768-779. [CrossRef]

31. Xu, M.; Liang, T.; Shi, M.; Chen, H. Graphene-like two-dimensional materials. Chem. Rev. 2013, 113, 3766-3798. [CrossRef]

32. Zeng, Y.; Zhu, Z.; Du, D.; Lin, Y. Nanomaterial-based electrochemical biosensors for food safety. J. Electroanal. Chem. 2016, 781. [CrossRef]

33. Beya, M.M.; Netzel, M.E.; Sultanbawa, Y.; Smyth, H.; Hoffman, L.C. Plant-based phenolic molecules as natural preservatives in comminuted meats: A review. Antioxidants 2021, 10, 263. [CrossRef]

34. Trasande, L.; Shaffer, R.M.; Sathyanarayana, S. Food additives and child health. Pediatrics 2018, 142. [CrossRef]

35. Jiang, L.; Ding, Y.; Jiang, F.; Li, L.; Mo, F. Electrodeposited nitrogen-doped graphene/carbon nanotubes nanocomposite as enhancer for simultaneous and sensitive voltammetric determination of caffeine and vanillin. Anal. Chim. Acta. 2014, 833, 22-28. [CrossRef] [PubMed]

36. Brunetti, G.; Kodešová, R.; Švecová, H.; Fér, M.; Nikodem, A.; Klement, A.; Grabic, R.; Šimůnek, J. On the use of mechanistic soil-plant uptake models: A comprehensive experimental and numerical analysis on the translocation of carbamazepine in green pea plants. Environ. Sci. Technol. 2021. [CrossRef]

37. Lin, K.-C.; Hong, C.-P.; Chen, S.-M. Simultaneous determination for toxic ractopamine and salbutamol in pork sample using hybrid carbon nanotubes. Sens. Actuators B Chem. 2013, 177, 428-436. [CrossRef] 
38. Mazzanti, G.; Di Sotto, A.; Daniele, C.; Battinelli, L.; Brambilla, G.; Fiori, M.; Loizzo, S.; Loizzo, A. A pharmacodynamic study on clenbuterol-induced toxicity: Beta1- and beta2-adrenoceptors involvement in guinea-pig tachycardia in an in vitro model. Food Chem. Toxicol. 2007, 45, 1694-1699. [CrossRef]

39. Li, W.; Luo, Y.; Yue, X.; Wu, J.; Wu, R.; Qiao, Y.; Peng, Q.; Shi, B.; Lin, B.; Chen, X. A novel microfluidic paper-based analytical device based on chemiluminescence for the determination of $\beta$-agonists in swine hair. Anal. Methods 2020, 12, $2317-2322$. [CrossRef]

40. Yikilmaz, Y.; Kuzukiran, O.; Erdogan, E.; Sen, F.; Kirmizibayrak, O.; Filazi, A. The determination of $\beta$-agonist residues in bovine tissues using liquid chromatography-tandem mass spectrometry. Biomed. Chromatogr. 2020, 34, e4926. [CrossRef]

41. Valdés, M.G.; González, A.C.V.; Calzón, J.A.G.; Díaz-García, M.E. Analytical nanotechnology for food analysis. Microchim. Acta 2009, 166, 1-19. [CrossRef]

42. Ganiyu, S.A.; Mabunmi, A.A.; Olurin, O.T.; Adeyemi, A.A.; Jegede, O.A.; Okeh, A. Assessment of microbial and heavy metal contamination in shallow hand-dug wells bordering Ona river, Southwest Nigeria. Environ. Monit. Assess. 2021, $193,126$. [CrossRef] [PubMed]

43. Mishra, G.K.; Barfidokht, A.; Tehrani, F.; Mishra, R.K. Food safety analysis using electrochemical biosensors. Foods 2018, 7, 141. [CrossRef]

44. Tombelli, S.; Minunni, M.; Mascini, M. Aptamers-based assays for diagnostics, environmental and food analysis. Biomol. Eng. 2007, 24, 191-200. [CrossRef]

45. Dwivedi, H.P.; Smiley, R.D.; Jaykus, L.A. Selection and characterization of DNA aptamers with binding selectivity to Campylobacter jejuni using whole-cell SELEX. Appl. Microbiol. Biotechnol. 2010, 87, 2323-2334. [CrossRef] [PubMed]

46. Navani, N.K.; Mok, W.K.; Yingfu, L. In vitro selection of protein-binding DNA aptamers as ligands for biosensing applications. Methods Mol. Biol. 2009, 504, 399-415. [CrossRef]

47. Ronkainen, N.J.; Halsall, H.B.; Heineman, W.R. Electrochemical biosensors. Chem. Soc. Rev. 2010, 39, 1747-1763. [CrossRef]

48. Santos, P.V.F.; Lopes, I.C.; Diculescu, V.C.; Oliveira-Brett, A.M. DNA—cyanobacterial hepatotoxins microcystin-LR and nodularin interaction: Electrochemical evaluation. Electroanalysis 2012, 24, 547-553. [CrossRef]

49. Hou, L.; Ding, Y.; Zhang, L.; Guo, Y.; Li, M.; Chen, Z.; Wu, X. An ultrasensitive competitive immunosensor for impedimetric detection of microcystin-LR via antibody-conjugated enzymatic biocatalytic precipitation. Sens. Actuators B Chem. 2016, 233, 63-70. [CrossRef]

50. Lin, Z.; Huang, H.; Xu, Y.; Gao, X.; Qiu, B.; Chen, X.; Chen, G. Determination of microcystin-LR in water by a label-free aptamer based electrochemical impedance biosensor. Talanta 2013, 103, 371-374. [CrossRef]

51. Vogiazi, V.; de la Cruz, A.; Mishra, S.; Shanov, V.; Heineman, W.R.; Dionysiou, D.D. A comprehensive review: Development of electrochemical biosensors for detection of cyanotoxins in freshwater. ACS Sens. 2019, 4, 1151-1173. [CrossRef]

52. Wei, Q.; Zhao, Y.; Du, B.; Wu, D.; Cai, Y.; Mao, K.; Li, H.; Xu, C. Nanoporous PtRu alloy enhanced nonenzymatic immunosensor for ultrasensitive detection of microcystin-LR. Adv. Funct. Mater. 2011, 21, 4193-4198. [CrossRef]

53. Grieshaber, D.; MacKenzie, R.; Vörös, J.; Reimhult, E. Electrochemical biosensors-Sensor principles and architectures. Sensors 2008, 8, 1400-1458. [CrossRef] [PubMed]

54. Chauhan, N.; Pundir, C.S. An amperometric acetylcholinesterase sensor based on $\mathrm{Fe}_{3} \mathrm{O}_{4}$ nanoparticle/multi-walled carbon nanotube-modified ITO-coated glass plate for the detection of pesticides. Electrochim. Acta 2012, 67, 79-86. [CrossRef]

55. Gao, Y.; Wang, M.; Yang, X.; Sun, Q.; Zhao, J. Rapid detection of quinoline yellow in soft drinks using polypyrrole/single-walled carbon nanotubes composites modified glass carbon electrode. J. Electroanal. Chem. 2014, 735, 84-89. [CrossRef]

56. Lan, M.; Chen, C.; Zhou, Q.; Teng, Y.; Zhao, H.; Niu, X. Voltammetric detection of microcystis genus specific-sequence with disposable screenprinted electrode modified with gold nanoparticles. Adv. Mater. Lett. 2010, 1, 217-224. [CrossRef]

57. Romani, A.; Minunni, M.; Mulinacci, N.; Pinelli, P.; Vincieri, F.F.; Del Carlo, M.; Mascini, M. Comparison among differential pulse voltammetry, amperometric biosensor, and HPLC/DAD analysis for polyphenol determination. J. Agric. Food Chem. 2000, 48, 1197-1203. [CrossRef]

58. Sullivan, C.; Lu, D.; Senecal, A.; Kurup, P. Voltammetric detection of arsenic (III) using gold nanoparticles modified carbon screen printed electrodes: Application for facile and rapid analysis in commercial apple juice. Food Chem. 2021, 352, 129327. [CrossRef]

59. Chaubey, A.; Malhotra, B.D. Mediated biosensors. Biosens. Bioelectron. 2002, 17, 441-456. [CrossRef]

60. Gerard, M.; Chaubey, A.; Malhotra, B.D. Application of conducting polymers to biosensors. Biosens. Bioelectron. 2002, 17, 345-359. [CrossRef]

61. Michael, D.J.; Wightman, R.M. Electrochemical monitoring of biogenic amine neurotransmission in real time. J. Pharm. Biomed. Anal. 1999, 19, 33-46. [CrossRef]

62. Pohanka, M.; Skládal, P. Electrochemical biosensors-principles and applications. J. Appl. Biomed. 2008, 6, 57-64. [CrossRef]

63. Tlili, A.; Abdelghani, A.; Ameur, S.; Jaffrezic-Renault, N. Impedance spectroscopy and affinity measurement of specific antibodyantigen interaction. Mater. Sci. Eng. C 2006, 26, 546-550. [CrossRef]

64. Ma, K.-S.; Zhou, H.; Zoval, J.; Madou, M. DNA hybridization detection by label free versus impedance amplifying label with impedance spectroscopy. Sens. Actuators B Chem. 2006, 114, 58-64. [CrossRef]

65. Patolsky, F.; Katz, E.; Bardea, A.; Willner, I. Enzyme-linked amplified electrochemical sensing of oligonucleotide-DNA interactions by means of the precipitation of an insoluble product and using impedance spectroscopy. Langmuir 1999, 15, 3703-3706. [CrossRef] 
66. Chai, C.; Oh, S.W. Electrochemical impedimetric biosensors for food safety. Food Sci. Biotechnol. 2020, 29, 879-887. [CrossRef]

67. Zhao, X.; Zhuang, H.; Yoon, S.-C.; Dong, Y.; Wang, W.; Zhao, W. Electrical impedance spectroscopy for quality assessment of meat and fish: A review on basic principles, measurement methods, and recent advances. J. Food Qual. 2017, 2017, 6370739. [CrossRef]

68. Amiri, M.; Bezaatpour, A.; Jafari, H.; Boukherroub, R.; Szunerits, S. Electrochemical methodologies for the detection of pathogens. ACS Sens. 2018, 3, 1069-1086. [CrossRef] [PubMed]

69. Hu, T.; Mei, X.; Wang, Y.; Weng, X.; Liang, R.; Wei, M. Two-dimensional nanomaterials: Fascinating materials in biomedical field. Sci. Bull. 2019, 64, 1707-1727. [CrossRef]

70. Wang, Z.; Yu, J.; Gui, R.; Jin, H.; Xia, Y. Carbon nanomaterials-based electrochemical aptasensors. Biosens. Bioelectron. 2016, 79, 136-149. [CrossRef]

71. Adhikari, B.R.; Govindhan, M.; Chen, A. Carbon nanomaterials based electrochemical sensors/biosensors for the sensitive detection of pharmaceutical and biological compounds. Sensors 2015, 15, 22490-22508. [CrossRef]

72. Cernat, A.; Tertiş, M.; Săndulescu, R.; Bedioui, F.; Cristea, A.; Cristea, C. Electrochemical sensors based on carbon nanomaterials for acetaminophen detection: A review. Anal. Chim. Acta 2015, 886, 16-28. [CrossRef]

73. Yadav, S.; Nair, S.S.; Sai, V.V.R.; Satija, J. Nanomaterials based optical and electrochemical sensing of histamine: Progress and perspectives. Food Res. Int. 2019, 119, 99-109. [CrossRef] [PubMed]

74. Vilian, A.T.E.; Dinesh, B.; Kang, S.M.; Krishnan, U.M.; Huh, Y.S.; Han, Y.K. Recent advances in molybdenum disulfide-based electrode materials for electroanalytical applications. Microchim. acta 2019, 186, 203. [CrossRef] [PubMed]

75. Ashley, J.; Shahbazi, M.A.; Kant, K.; Chidambara, V.A.; Wolff, A.; Bang, D.D.; Sun, Y. Molecularly imprinted polymers for sample preparation and biosensing in food analysis: Progress and perspectives. Biosens. Bioelectron. 2017, 91, 606-615. [CrossRef]

76. Mao, Y.; Bao, Y.; Gan, S.; Li, F.; Niu, L. Electrochemical sensor for dopamine based on a novel graphene-molecular imprinted polymers composite recognition element. Biosens. Bioelectron. 2011, 28, 291-297. [CrossRef] [PubMed]

77. Kim, Y.J.; Kim, Y.S.; Niazi, J.H.; Gu, M.B. Electrochemical aptasensor for tetracycline detection. Bioprocess. Biosyst. Eng. 2010, 33, 31-37. [CrossRef]

78. Qiu, H.; Sun, Y.; Huang, X.; Qu, Y. A sensitive nanoporous gold-based electrochemical aptasensor for thrombin detection. Colloids Surf. B 2010, 79, 304-308. [CrossRef]

79. Deng, C.; Chen, J.; Nie, Z.; Wang, M.; Chu, X.; Chen, X.; Xiao, X.; Lei, C.; Yao, S. Impedimetric aptasensor with femtomolar sensitivity based on the enlargement of surface-charged gold nanoparticles. Anal. Chem. 2009, 81, 739-745. [CrossRef] [PubMed]

80. Wan, J.; Lacey, S.D.; Dai, J.; Bao, W.; Fuhrer, M.S.; Hu, L. Tuning two-dimensional nanomaterials by intercalation: Materials, properties and applications. Chem. Soc. Rev. 2016, 45, 6742-6765. [CrossRef]

81. Wang, H.; Yuan, H.; Sae Hong, S.; Li, Y.; Cui, Y. Physical and chemical tuning of two-dimensional transition metal dichalcogenides. Chem. Soc. Rev. 2015, 44, 2664-2680. [CrossRef]

82. Wang, H.; Feng, H.; Li, J. Graphene and graphene-like layered transition metal dichalcogenides in energy conversion and storage. Small 2014, 10, 2165-2181. [CrossRef] [PubMed]

83. Sun, Y.; Lei, F.; Gao, S.; Pan, B.; Zhou, J.; Xie, Y. Atomically thin tin dioxide sheets for efficient catalytic oxidation of carbon monoxide. Angew. Chem. 2013, 52, 10569-10572. [CrossRef]

84. Xia, F.; Wang, H.; Xiao, D.; Dubey, M.; Ramasubramaniam, A. Two-dimensional material nanophotonics. Nat. Photon. 2014, 8, 899-907. [CrossRef]

85. He, Q.; Wu, S.; Yin, Z.; Zhang, H. Graphene-based electronic sensors. Chem. Sci. 2012, 3, 1764-1772. [CrossRef]

86. Pumera, M.; Ambrosi, A.; Bonanni, A.; Chng, E.L.K.; Poh, H.L. Graphene for electrochemical sensing and biosensing. Trends Anal. Chem. 2010, 29, 954-965. [CrossRef]

87. Liu, Y.; Dong, X.; Chen, P. Biological and chemical sensors based on graphene materials. Chem. Soc. Rev. 2012, 41, $2283-2307$. [CrossRef]

88. Tyagi, D.; Wang, H.; Huang, W.; Hu, L.; Tang, Y.; Guo, Z.; Ouyang, Z.; Zhang, H. Recent advances in two-dimensionalmaterial-based sensing technology toward health and environmental monitoring applications. Nanoscale 2020, 12, 3535-3559. [CrossRef]

89. Tan, C.; Cao, X.; Wu, X.-J.; He, Q.; Yang, J.; Zhang, X.; Chen, J.; Zhao, W.; Han, S.; Nam, G.-H.; et al. Recent advances in ultrathin two-dimensional nanomaterials. Chem. Rev. 2017, 117, 6225-6331. [CrossRef] [PubMed]

90. Han, W.; Zang, C.; Huang, Z.; Zhang, H.; Ren, L.; Qi, X.; Zhong, J. Enhanced photocatalytic activities of three-dimensional graphene-based aerogel embedding $\mathrm{TiO}_{2}$ nanoparticles and loading $\mathrm{MoS}_{2}$ nanosheets as Co-catalyst. Int. J. Hydrogen Energy 2014, 39, 19502-19512. [CrossRef]

91. Zhang, Z.; Liu, Y.D.; Ren, L.; Zhang, H.; Huang, Z.Y.; Qi, X.; Wei, X.L.; Zhong, J.X. Three-dimensional-networked Ni-Co-Se nanosheet/nanowire arrays on carbon cloth: A flexible electrode for efficient hydrogen evolution. Electrochim. Acta 2016, 200, 142-151. [CrossRef]

92. Ren, X.; Zhou, J.; Qi, X.; Liu, Y.; Huang, Z.; Li, Z.; Ge, Y.; Dhanabalan, S.C.; Ponraj, J.S.; Wang, S.; et al. Few-layer black phosphorus nanosheets as electrocatalysts for highly efficient oxygen evolution reaction. Adv. Energy Mater. 2017, 7, 1700396. [CrossRef]

93. Varghese, S.S.; Varghese, S.H.; Swaminathan, S.; Singh, K.K.; Mittal, V. Two-dimensional materials for sensing: Graphene and beyond. Electronics 2015, 4, 651-687. [CrossRef]

94. Liu, Y.; Weiss, N.O.; Duan, X.; Cheng, H.-C.; Huang, Y.; Duan, X. Van der Waals heterostructures and devices. Nat. Rev. Mater. 2016, 1, 16042. [CrossRef] 
95. Kurapati, R.; Kostarelos, K.; Prato, M.; Bianco, A. Biomedical uses for 2D materials beyond graphene: Current advances and challenges ahead. Adv. Mater. 2017, 29. [CrossRef] [PubMed]

96. Cao, X.; Halder, A.; Tang, Y.; Hou, C.; Wang, H.; Duus, J.Ø.; Chi, Q. Engineering two-dimensional layered nanomaterials for wearable biomedical sensors and power devices. Mater. Chem. Front. 2018, 2, 1944-1986. [CrossRef]

97. Park, K.O.; Lee, J.H.; Park, J.H.; Shin, Y.C.; Huh, J.B.; Bae, J.-H.; Kang, S.H.; Hong, S.W.; Kim, B.; Yang, D.J.; et al. Graphene oxide-coated guided bone regeneration membranes with enhanced osteogenesis: Spectroscopic analysis and animal study. Appl. Spectro. Rev. 2016, 51, 540-551. [CrossRef]

98. Shin, Y.C.; Kim, J.; Kim, S.E.; Song, S.-J.; Hong, S.W.; Oh, J.-W.; Lee, J.; Park, J.-C.; Hyon, S.-H.; Han, D.-W. RGD peptide and graphene oxide co-functionalized PLGA nanofiber scaffolds for vascular tissue engineering. Regen. Biomater. 2017, 4, 159-166. [CrossRef]

99. Dai, C.; Chen, Y.; Jing, X.; Xiang, L.; Yang, D.; Lin, H.; Liu, Z.; Han, X.; Wu, R. Two-dimensional tantalum carbide (MXenes) composite nanosheets for multiple imaging-guided photothermal tumor ablation. ACS Nano 2017, 11, 12696-12712. [CrossRef] [PubMed]

100. Liu, Z.; Lin, H.; Zhao, M.; Dai, C.; Zhang, S.; Peng, W.; Chen, Y. 2D Superparamagnetic tantalum carbide composite MXenes for efficient breast-cancer theranostics. Theranostics 2018, 8, 1648-1664. [CrossRef]

101. Wang, S.; Chen, Y.; Li, X.; Gao, W.; Zhang, L.; Liu, J.; Zheng, Y.; Chen, H.; Shi, J. Injectable 2D MoS 2 -integrated drug delivering implant for highly efficient NIR-triggered synergistic tumor hyperthermia. Adv. Mater. 2015, 27, 7117-7122. [CrossRef] [PubMed]

102. Zhu, Y.; Wang, Y.; Williams, G.R.; Fu, L.; Wu, J.; Wang, H.; Liang, R.; Weng, X.; Wei, M. Multicomponent transition metal dichalcogenide nanosheets for imaging-guided photothermal and chemodynamic therapy. Adv. Sci. 2020, 7, 2000272. [CrossRef] [PubMed]

103. Song, S.J.; Shin, Y.C.; Lee, H.U.; Kim, B.; Han, D.W.; Lim, D. Dose- and time-dependent cytotoxicity of layered black phosphorus in fibroblastic cells. Nanomaterials 2018, 8, 408. [CrossRef]

104. Shi, S.; Huang, Y.; Chen, X.; Weng, J.; Zheng, N. Optimization of surface coating on small Pd nanosheets for in vivo near-infrared photothermal therapy of tumor. ACS Appl. Mater. Interfaces 2015, 7, 14369-14375. [CrossRef] [PubMed]

105. Raja, I.S.; Kang, M.S.; Kim, K.S.; Jung, Y.J.; Han, D.-W. Two-dimensional theranostic nanomaterials in cancer treatment: State of the art and perspectives. Cancers 2020,12, 1657. [CrossRef]

106. Omomo, Y.; Sasaki, T.; Wang, L.; Watanabe, M. Redoxable nanosheet crystallites of $\mathrm{MnO}_{2}$ derived via delamination of a layered manganese oxide. J. Am. Chem. Soc. 2003, 125, 3568-3575. [CrossRef] [PubMed]

107. Li, Y.T.; Qu, L.L.; Li, D.W.; Song, Q.X.; Fathi, F.; Long, Y.T. Rapid and sensitive in-situ detection of polar antibiotics in water using a disposable Ag-graphene sensor based on electrophoretic preconcentration and surface-enhanced Raman spectroscopy. Biosens. Bioelectron. 2013, 43, 94-100. [CrossRef] [PubMed]

108. Liu, Y.; Yu, D.; Zeng, C.; Miao, Z.; Dai, L. Biocompatible graphene oxide-based glucose biosensors. Langmuir 2010, 26, 6158-6160. [CrossRef]

109. Zhu, Z.; Garcia-Gancedo, L.; Flewitt, A.J.; Xie, H.; Moussy, F.; Milne, W.I. A critical review of glucose biosensors based on carbon nanomaterials: Carbon nanotubes and graphene. Sensors 2012, 12, 5996-6022. [CrossRef]

110. Jin, L.; Lee, J.H.; Jin, O.S.; Shin, Y.C.; Kim, M.J.; Hong, S.W.; Lee, M.H.; Park, J.C.; Han, D.W. Stimulated osteogenic differentiation of human mesenchymal stem cells by reduced graphene oxide. J. Nanosci. Nanotechnol. 2015, 15, 7966-7970. [CrossRef]

111. Kim, J.W.; Shin, Y.C.; Lee, J.J.; Bae, E.B.; Jeon, Y.C.; Jeong, C.M.; Yun, M.J.; Lee, S.H.; Han, D.W.; Huh, J.B. The effect of reduced graphene oxide-coated biphasic calcium phosphate bone graft material on osteogenesis. Int. J. Mol. Sci. 2017, 18, 1725. [CrossRef]

112. Ou, L.; Song, B.; Liang, H.; Liu, J.; Feng, X.; Deng, B.; Sun, T.; Shao, L. Toxicity of graphene-family nanoparticles: A general review of the origins and mechanisms. Part. Fibre Toxicol. 2016, 13, 57. [CrossRef]

113. Malhotra, N.; Villaflores, O.B.; Audira, G.; Siregar, P.; Lee, J.-S.; Ger, T.-R.; Hsiao, C.-D. Toxicity studies on graphene-based nanomaterials in aquatic organisms: Current understanding. Molecules 2020, 25, 3618. [CrossRef]

114. Geim, A.K.; Novoselov, K.S. The rise of graphene. Nat. Mater. 2007, 6, 183-191. [CrossRef] [PubMed]

115. Shang, N.G.; Papakonstantinou, P.; McMullan, M.; Chu, M.; Stamboulis, A.; Potenza, A.; Dhesi, S.S.; Marchetto, H. Catalyst-free efficient growth, orientation and biosensing properties of multilayer graphene nanoflake films with sharp edge planes. Adv. Funct. Mater. 2008, 18, 3506-3514. [CrossRef]

116. Liu, N.; Luo, F.; Wu, H.; Liu, Y.; Zhang, C.; Chen, J. One-step ionic-liquid-assisted electrochemical synthesis of ionic-liquidfunctionalized graphene sheets directly from graphite. Adv. Funct. Mater. 2008, 18, 1518-1525. [CrossRef]

117. Caccamo, D.; Currò, M.; Ientile, R.; Verderio, E.A.; Scala, A.; Mazzaglia, A.; Pennisi, R.; Musarra-Pizzo, M.; Zagami, R.; Neri, G.; et al. Intracellular fate and impact on gene expression of doxorubicin/cyclodextrin-graphene nanomaterials at sub-toxic concentration. Int. J. Mol. Sci. 2020, 21, 4891. [CrossRef]

118. Hong, S.W.; Lee, J.H.; Kang, S.H.; Hwang, E.Y.; Hwang, Y.-S.; Lee, M.H.; Han, D.-W.; Park, J.-C. Enhanced neural cell adhesion and neurite outgrowth on graphene-based biomimetic substrates. Biomed. Res. Int. 2014, 2014, 212149. [CrossRef] [PubMed]

119. Sharma, H.; Mondal, S. Functionalized graphene oxide for chemotherapeutic drug delivery and cancer treatment: A promising material in nanomedicine. Int. J. Mol. Sci. 2020, 21, 6280. [CrossRef] [PubMed]

120. Choi, Y.-J.; Gurunathan, S.; Kim, J.-H. Graphene oxide-silver nanocomposite enhances cytotoxic and apoptotic potential of salinomycin in human ovarian cancer stem cells (OvCSCs): A novel approach for cancer therapy. Int. J. Mol. Sci. 2018, 19, 710. [CrossRef] 
121. Becheru, D.F.; Vlăsceanu, G.M.; Banciu, A.; Vasile, E.; Ioniţă, M.; Burns, J.S. Optical graphene-based biosensor for nucleic acid detection; influence of graphene functionalization and ionic strength. Int. J. Mol. Sci. 2018, 19, 3230. [CrossRef]

122. Wang, B.; Shen, J.; Huang, Y.; Liu, Z.; Zhuang, H. Graphene quantum dots and enzyme-coupled biosensor for highly sensitive determination of hydrogen peroxide and glucose. Int. J. Mol. Sci. 2018, 19, 1696. [CrossRef] [PubMed]

123. Yang, T.; Yang, R.; Chen, H.; Nan, F.; Ge, T.; Jiao, K. Electrocatalytic activity of molybdenum disulfide nanosheets enhanced by self-doped polyaniline for highly sensitive and synergistic determination of adenine and guanine. ACS Appl. Mater. Interfaces 2015, 7, 2867-2872. [CrossRef] [PubMed]

124. Campuzano, S.; Pedrero, M.; Nikoleli, G.P.; Pingarrón, J.M.; Nikolelis, D.P. Hybrid 2D-nanomaterials-based electrochemical immunosensing strategies for clinical biomarkers determination. Biosens. Bioelectron. 2017, 89, 269-279. [CrossRef]

125. Arshad, M.M.; Gopinath, S.C.; Norhaimi, W.M.W.; Fathil, M.F.M. Current and future envision on developing biosensors aided by 2D molybdenum disulfide (MoS2) productions. Biosens. Bioelectron. 2019, 132, 248-264. [CrossRef]

126. Pumera, M. Phosphorene and black phosphorus for sensing and biosensing. Trends Anal. Chem. 2017, 93, 1-6. [CrossRef]

127. Cai, J.; Sun, B.; Li, W.; Gou, X.; Gou, Y.; Li, D.; Hu, F. Novel nanomaterial of porous graphene functionalized black phosphorus as electrochemical sensor platform for bisphenol A detection. J. Electroanal. Chem. 2019, 835, 1-9. [CrossRef]

128. Wu, J.; Zhou, T.; Wang, Q.; Umar, A. Morphology and chemical composition dependent synthesis and electrochemical properties of MnO2-based nanostructures for efficient hydrazine detection. Sens. Actuators B Chem. 2016, 224, 878-884. [CrossRef]

129. Yao, W.; Zhou, H.; Lu, Y. Synthesis and property of novel $\mathrm{MnO}_{2} @$ polypyrrole coaxial nanotubes as electrode material for supercapacitors. J. Power Sources 2013, 241, 359-366. [CrossRef]

130. Thangarasu, R.; Victor, V. $\mathrm{MnO}_{2}$ /PANI/rGO-A modified carbon electrode based electrochemical sensor to detect organophosphate pesticide in real food samples. Anal. Bioanal. Electrochem. 2019, 11, 427-447.

131. Therias, S.; Mousty, C. Electrodes modified with synthetic anionic clays. Appl. Clay Sci. 1995, 10, 147-162. [CrossRef]

132. Shan, D.; Cosnier, S.; Mousty, C. Layered Double Hydroxides: An attractive material for electrochemical biosensor design. Anal. Chem. 2003, 75, 3872-3879. [CrossRef]

133. Tajik, S.; Beitollahi, H.; Nejad, F.G.; Zhang, K.; Le, Q.V.; Jang, H.W.; Kim, S.Y.; Shokouhimehr, M. Recent advances in electrochemical sensors and biosensors for detecting bisphenol A. Sensors 2020, 20, 3364. [CrossRef] [PubMed]

134. Shahzad, F.; Zaidi, S.A.; Naqvi, R.A. 2D transition metal carbides (MXene) for electrochemical sensing: A review. Crit. Rev. Anal. Chem. 2020, 1-17. [CrossRef]

135. Lu, L.; Seenivasan, R.; Wang, Y.-C.; Yu, J.-H.; Gunasekaran, S. An electrochemical immunosensor for rapid and sensitive detection of mycotoxins fumonisin B1 and deoxynivalenol. Electrochim. Acta 2016, 213, 89-97. [CrossRef]

136. Eissa, S.; Zourob, M. A graphene-based electrochemical competitive immunosensor for the sensitive detection of okadaic acid in shellfish. Nanoscale 2012, 4, 7593-7599. [CrossRef]

137. Soares, R.R.A.; Hjort, R.G.; Pola, C.C.; Parate, K.; Reis, E.L.; Soares, N.F.F.; McLamore, E.S.; Claussen, J.C.; Gomes, C.L. Laserinduced graphene electrochemical immunosensors for rapid and label-free monitoring of salmonella enterica in chicken broth ACS Sens. 2020, 5, 1900-1911. [CrossRef]

138. Tang, J.; Hou, L.; Tang, D.; Zhou, J.; Wang, Z.; Li, J.; Chen, G. Magneto-controlled electrochemical immunoassay of brevetoxin B in seafood based on guanine-functionalized graphene nanoribbons. Biosens. Bioelectron. 2012, 38, 86-93. [CrossRef]

139. Bulbul, G.; Hayat, A.; Andreescu, S. A generic amplification strategy for electrochemical aptasensors using a non-enzymatic nanoceria tag. Nanoscale 2015, 7, 13230-13238. [CrossRef]

140. Wang, J.; Yang, Q.; Zhang, L.; Liu, M.; Hu, N.; Zhang, W.; Zhu, W.; Wang, R.; Suo, Y.; Wang, J. A hybrid monolithic column based on layered double hydroxide-alginate hydrogel for selective solid phase extraction of lead ions in food and water samples. Food Chem. 2018, 257, 155-162. [CrossRef]

141. Mohammad-Razdari, A.; Ghasemi-Varnamkhasti, M.; Rostami, S.; Izadi, Z.; Ensafi, A.A.; Siadat, M. Development of an electrochemical biosensor for impedimetric detection of tetracycline in milk. J. Food Sci. Technol. 2020, 57, 4697-4706. [CrossRef]

142. Zhao, Y.; Zheng, X.; Wang, Q.; Zhe, T.; Bai, Y.; Bu, T.; Zhang, M.; Wang, L. Electrochemical behavior of reduced graphene oxide/cyclodextrins sensors for ultrasensitive detection of imidacloprid in brown rice. Food Chem. 2020, 333, 127495. [CrossRef] [PubMed]

143. Chan, C.; Guo, J.; Sun, C.; Tsang, M.; Tian, F.; Hao, J.; Chen, S.; Yang, M. A reduced graphene oxide-Au based electrochemical biosensor for ultrasensitive detection of enzymatic activity of botulinum neurotoxin A. Sens. Actuators B Chem. 2015, 220. [CrossRef]

144. Poo-arporn, Y.; Pakapongpan, S.; Chanlek, N.; Poo-arporn, R.P. The development of disposable electrochemical sensor based on $\mathrm{Fe}_{3} \mathrm{O}_{4}$-doped reduced graphene oxide modified magnetic screen-printed electrode for ractopamine determination in pork sample. Sens. Actuators B Chem. 2019, 284, 164-171. [CrossRef]

145. Zhao, F.; Yao, Y.; Li, X.; Lan, L.; Jiang, C.; Ping, J. Metallic transition metal dichalcogenide nanosheets as an effective and biocompatible transducer for electrochemical detection of pesticide. Anal. Chem. 2018, 90, 11658-11664. [CrossRef] [PubMed]

146. Ramaraj, S.; Sakthivel, M.; Chen, S.-M.; Ho, K.-C. Ultrasound-assisted synthesis of two-dimensional layered ytterbium substituted molybdenum diselenide nanosheets with excellent electrocatalytic activity for the electrochemical detection of diphenylamine anti-scald agent in fruit extract. Ultrason. Sonochem. 2019, 50, 265-277. [CrossRef]

147. Xu, J.; Qiao, X.; Wang, Y.; Sheng, Q.; Yue, T.; Zheng, J.; Zhou, M. Electrostatic assembly of gold nanoparticles on black phosphorus nanosheets for electrochemical aptasensing of patulin. Microchim. Acta 2019, 186, 238. [CrossRef] 
148. Berdalet, E.; Fleming, L.E.; Gowen, R.; Davidson, K.; Hess, P.; Backer, L.C.; Moore, S.K.; Hoagland, P.; Enevoldsen, H. Marine harmful algal blooms, human health and wellbeing: Challenges and opportunities in the 21st century. J. Mar. Biol. Assoc. UK 2015, 96, 61-91. [CrossRef]

149. Callejas, L.; Darce, A.C.M.; Amador, J.J.; Conklin, L.; Gaffga, N.; Schurz Rogers, H.; DeGrasse, S.; Hall, S.; Earley, M.; Mei, J.; et al. Paralytic shellfish poisonings resulting from an algal bloom in Nicaragua. BMC Res. Notes 2015, 8, 74. [CrossRef] [PubMed]

150. Cusick, K.D.; Sayler, G.S. An overview on the marine neurotoxin, saxitoxin: Genetics, molecular targets, methods of detection and ecological functions. Marine Drugs 2013, 11, 991-1018. [CrossRef] [PubMed]

151. Eangoor, P.; Indapurkar, A.S.; Vakkalanka, M.; Yeh, J.S.; Knaack, J.S. Rapid and sensitive ELISA screening assay for several paralytic shellfish toxins in human urine. J. Anal. Toxicol. 2017, 41, 755-759. [CrossRef]

152. Blanco, J. Accumulation of dinophysis toxins in bivalve molluscs. Toxins 2018, 10, 453. [CrossRef] [PubMed]

153. Mestrović, V.; Pavela-Vrancic, M. Inhibition of alkaline phosphatase activity by okadaic acid, a protein phosphatase inhibitor. Biochimie 2003, 85, 647-650. [CrossRef]

154. Dounay, A.B.; Forsyth, C.J. Okadaic acid: The archetypal serine/threonine protein phosphatase inhibitor. Curr. Med. Chem. 2002, 9, 1939-1980. [CrossRef]

155. Kreuzer, M.P.; Pravda, M.; O'Sullivan, C.K.; Guilbault, G.G. Novel electrochemical immunosensors for seafood toxin analysis. Toxicon 2002, 40, 1267-1274. [CrossRef]

156. Law, J.W.-F.; Ab Mutalib, N.-S.; Chan, K.-G.; Lee, L.-H. Rapid methods for the detection of foodborne bacterial pathogens: Principles, applications, advantages and limitations. Front. Microbiol. 2015, 5. [CrossRef] [PubMed]

157. Wang, Z.; Ramsdell, J.S. Analysis of interactions of brevetoxin-b and human serum albumin by liquid chromatography/mass spectrometry. Chem. Res. Toxicol. 2011, 24, 54-64. [CrossRef]

158. Chen, W.; Colon, R.; Louda, J.W.; del Rey, F.R.; Durham, M.; Rein, K.S. Brevetoxin (PbTx-2) influences the redox status and NPQ of Karenia brevis by way of thioredoxin reductase. Harmful Algae 2018, 71, 29-39. [CrossRef]

159. Fernández-Cruz, M.L.; Mansilla, M.L.; Tadeo, J.L. Mycotoxins in fruits and their processed products: Analysis, occurrence and health implications. J. Adv. Res. 2010, 1, 113-122. [CrossRef]

160. Pfohl-Leszkowicz, A.; Manderville, R.A. Ochratoxin A: An overview on toxicity and carcinogenicity in animals and humans. Mol Nutr. Food Res. 2007, 51, 61-99. [CrossRef]

161. Mally, A.; Pepe, G.; Ravoori, S.; Fiore, M.; Gupta, R.C.; Dekant, W.; Mosesso, P. Ochratoxin a causes DNA damage and cytogenetic effects but no DNA adducts in rats. Chem. Res. Toxicol. 2005, 18, 1253-1261. [CrossRef]

162. Rousseau, M.-C.; Parent, M.-E.; Nadon, L.; Latreille, B.; Siemiatycki, J. Occupational exposure to lead compounds and risk of cancer among men: A population-based case-control study. Am. J. Epidemiol. 2007, 166, 1005-1014. [CrossRef]

163. Buszewski, B.; Szultka, M. Past, present, and future of solid phase extraction: A review. Crit. Rev. Anal. Chem. 2012, 42, 198-213. [CrossRef]

164. Mohammed, A.M.; Rahim, R.A.; Ibraheem, I.J.; Loong, F.K.; Hisham, H.; Hashim, U.; Al-Douri, Y. Application of Gold Nanoparticles for Electrochemical DNA Biosensor. J. Nanomater. 2014, 2014, 683460. [CrossRef]

165. Yáñez-Sedeño, P.; Pingarrón, J. Gold nanoparticle-based electrochemical biosensors. Anal. Bioanal. Chem. 2005, 382, 884-886. [CrossRef]

166. Ouyang, Q.; Liu, Y.; Chen, Q.; Guo, Z.; Zhao, J.; Li, H.; Hu, W. Rapid and specific sensing of tetracycline in food using a novel upconversion aptasensor. Food Control 2017, 81, 156-163. [CrossRef]

167. Kim, Y.S.; Kim, J.H.; Kim, I.A.; Lee, S.J.; Jurng, J.; Gu, M.B. A novel colorimetric aptasensor using gold nanoparticle for a highly sensitive and specific detection of oxytetracycline. Biosens. Bioelectron. 2010, 26, 1644-1649. [CrossRef] [PubMed]

168. Shen, L.; Chen, J.; Li, N.; He, P.; Li, Z. Rapid colorimetric sensing of tetracycline antibiotics with in situ growth of gold nanoparticles. Anal. Chim. Acta 2014, 839, 83-90. [CrossRef]

169. Hou, J.; Zhang, H.; Yang, Q.; Li, M.; Jiang, L.; Song, Y. Hydrophilic-hydrophobic patterned molecularly imprinted photonic crystal sensors for high-sensitive colorimetric detection of tetracycline. Small 2015, 11, 2738-2742. [CrossRef]

170. Rózsa, G.; Náfrádi, M.; Alapi, T.; Schrantz, K.; Szabó, L.; Wojnárovits, L.; Takács, E.; Tungler, A. Photocatalytic, photolytic and radiolytic elimination of imidacloprid from aqueous solution: Reaction mechanism, efficiency and economic considerations. Appl. Catal. B 2019, 250, 429-439. [CrossRef]

171. Wang, Q.; Liu, Y.; Bai, Y.; Yao, S.; Wei, Z.; Zhang, M.; Wang, L.; Wang, L. Superhydrophobic SERS substrates based on silver dendrite-decorated filter paper for trace detection of nitenpyram. Anal. Chim. Acta 2019, 1049, 170-178. [CrossRef]

172. Hayat, W.; Zhang, Y.; Hussain, I.; Du, X.; Du, M.; Yao, C.; Huang, S.; Si, F. Efficient degradation of imidacloprid in water through iron activated sodium persulfate. Chem. Eng. J. 2019, 370, 1169-1180. [CrossRef]

173. DasGupta, B.R.; Foley, J., Jr. C. botulinum neurotoxin types A and E: Isolated light chain breaks down into two fragments. Comparison of their amino acid sequences with tetanus neurotoxin. Biochimie 1989, 71, 1193-1200. [CrossRef]

174. Sobel, J.; Tucker, N.; Sulka, A.; McLaughlin, J.; Maslanka, S. Foodborne botulism in the United States, 1990-2000. Emerg. Infect. Dis. 2004, 10, 1606-1611. [CrossRef]

175. Foran, P.G.; Mohammed, N.; Lisk, G.O.; Nagwaney, S.; Lawrence, G.W.; Johnson, E.; Smith, L.; Aoki, K.R.; Dolly, J.O. Evaluation of the therapeutic usefulness of botulinum neurotoxin B, C1, E, and F compared with the long lasting type A. Basis for distinct durations of inhibition of exocytosis in central neurons. J. Biol. Chem. 2003, 278, 1363-1371. [CrossRef] [PubMed] 
176. Zhang, Y.; Wang, F.; Fang, L.; Wang, S.; Fang, G. Rapid determination of ractopamine residues in edible animal products by enzyme-linked immunosorbent assay: Development and investigation of matrix effects. J. Biomed. Biotechnol. 2009, 2009, 579175. [CrossRef]

177. Yaeger, M.J.; Mullin, K.; Ensley, S.M.; Ware, W.A.; Slavin, R.E. Myocardial toxicity in a group of greyhounds administered ractopamine. Vet. Pathol. 2012, 49, 569-573. [CrossRef]

178. Brambilla, G.; Cenci, T.; Franconi, F.; Galarini, R.; Macrì, A.; Rondoni, F.; Strozzi, M.; Loizzo, A. Clinical and pharmacological profile in a clenbuterol epidemic poisoning of contaminated beef meat in Italy. Toxicol. Lett. 2000, 114, 47-53. [CrossRef]

179. Peng, T.; Royer, A.-L.; Guitton, Y.; Le Bizec, B.; Dervilly-Pinel, G. Serum-based metabolomics characterization of pigs treated with ractopamine. Metabolomics 2017, 13, 77. [CrossRef]

180. Lin, X.; Ni, Y.; Kokot, S. A novel electrochemical sensor for the analysis of $\beta$-agonists: The poly(acid chrome blue K)/graphene oxide-nafion/glassy carbon electrode. J. Hazard. Mater. 2013, 260, 508-517. [CrossRef]

181. He, P.; Shen, L.; Liu, R.; Luo, Z.; Li, Z. Direct detection of $\beta$-agonists by use of gold nanoparticle-based colorimetric assays. Anal. Chem. 2011, 83, 6988-6995. [CrossRef]

182. Kaur, N.; Prabhakar, N. Current scenario in organophosphates detection using electrochemical biosensors. Trends Anal. Chem. 2017, 92, 62-85. [CrossRef]

183. Tang, W.; Yang, J.; Wang, F.; Wang, J.; Li, Z. Thiocholine-triggered reaction in personal glucose meters for portable quantitative detection of organophosphorus pesticide. Anal. Chim. Acta 2019, 1060, 97-102. [CrossRef] [PubMed]

184. Vinoth Kumar, J.; Karthik, R.; Chen, S.-M.; Natarajan, K.; Karuppiah, C.; Yang, C.-C.; Muthuraj, V. 3D flower-like gadolinium molybdate catalyst for efficient detection and degradation of organophosphate pesticide (fenitrothion). ACS Appl. Mater. Interfaces 2018, 10, 15652-15664. [CrossRef]

185. Hande, P.E.; Samui, A.B.; Kulkarni, P.S. An efficient method for determination of the diphenylamine (stabilizer) in propellants by molecularly imprinted polymer based carbon paste electrochemical sensor. Propell. Explos. Pyrotech. 2017, 42, 376-380. [CrossRef]

186. Robatscher, P.; Eisenstecken, D.; Sacco, F.; Pöhl, H.; Berger, J.; Zanella, A.; Oberhuber, M. Diphenylamine residues in apples caused by contamination in fruit storage facilities. J. Agric. Food Chem. 2012, 60, 2205-2211. [CrossRef] [PubMed]

187. Farokhcheh, A.; Alizadeh, N. Determination of diphenylamine residue in fruit samples using spectrofluorimetry and multivariate analysis. LWT-Food Sci. Technol. 2013, 54, 6-12. [CrossRef]

188. Granado, V.L.V.; Gutiérrez-Capitán, M.; Fernández-Sánchez, C.; Gomes, M.T.S.R.; Rudnitskaya, A.; Jimenez-Jorquera, C. Thin-film electrochemical sensor for diphenylamine detection using molecularly imprinted polymers. Anal. Chim. Acta 2014, 809, 141-147. [CrossRef]

189. Marín, S.; Mateo, E.M.; Sanchis, V.; Valle-Algarra, F.M.; Ramos, A.J.; Jiménez, M. Patulin contamination in fruit derivatives, including baby food, from the Spanish market. Food Chem. 2011, 124, 563-568. [CrossRef]

190. Wu, S.; Duan, N.; Zhang, W.; Zhao, S.; Wang, Z. Screening and development of DNA aptamers as capture probes for colorimetric detection of patulin. Anal. Biochem. 2016, 508, 58-64. [CrossRef]

191. Li, X.; Li, H.; Li, X.; Zhang, Q. Determination of trace patulin in apple-based food matrices. Food Chem. 2017, $233,290-301$. [CrossRef] [PubMed]

192. Monzó, J.; Insua, I.; Fernandez-Trillo, F.; Rodriguez, P. Fundamentals, achievements and challenges in the electrochemical sensing of pathogens. Analyst 2015, 140, 7116-7128. [CrossRef] [PubMed]

193. Tan, E.L.; Ng, W.N.; Shao, R.; Pereles, B.D.; Ong, K.G. A wireless, passive sensor for quantifying packaged food quality. Sensors 2007, 7, 1747-1756. [CrossRef] [PubMed]

194. Goode, J.A.; Rushworth, J.V.; Millner, P.A. biosensor regeneration: A review of common techniques and outcomes. Langmuir 2015, 31, 6267-6276. [CrossRef]

195. Zhao, M.; Wang, P.; Guo, Y.; Wang, L.; Luo, F.; Qiu, B.; Guo, L.; Su, X.; Lin, Z.; Chen, G. Detection of aflatoxin B(1) in food samples based on target-responsive aptamer-cross-linked hydrogel using a handheld $\mathrm{pH}$ meter as readout. Talanta 2018, 176, 34-39. [CrossRef]

196. Yousefi, H.; Su, H.M.; Imani, S.M.; Alkhaldi, K.; MFilipe, C.D.; Didar, T.F. Intelligent food packaging: A review of smart sensing technologies for monitoring food quality. ACS Sens. 2019, 4, 808-821. [CrossRef] [PubMed]

197. Yoon, J.; Cho, H.-Y.; Shin, M.; Choi, H.K.; Lee, T.; Choi, J.-W. Flexible electrochemical biosensors for healthcare monitoring. J. Mater. Chem. B 2020, 8, 7303-7318. [CrossRef] 